Bogusław Tracz

https://orcid.org/0000-0002-0896-1602

Biuro Badań Historycznych Instytutu Pamięci Narodowej

\title{
Obrzeża subkultury czy ruch religijny? Satanizm młodzieżowy w Polsce w latach osiemdziesiątych XX wieku
}

\begin{abstract}
Zarys treści: Artykuł jest próbą przedstawienia dziejów satanizmu młodzieżowego, który pojawił się w Polsce u progu lat osiemdziesiątych XX w., wraz napływem mody na heavy metal i ukształtowaniem się subkultury młodzieżowej zgromadzonej wokół tej muzyki oraz jej podgatunków. Przedstawione zostało kulturowe tło powstania i rozwoju współczesnego satanizmu w USA i na zachodzie Europy, a następnie jego recepcja w Polsce lat osiemdziesiątych XX w., która następowała z jednej strony w oderwaniu od amerykańskich i zachodnioeuropejskich źródeł tego zjawiska, z drugiej zaś była próbą jego skopiowania $\mathrm{w}$ warunkach społeczeństwa niedemokratycznego i jednocześnie w dużej mierze tradycyjnego. Przedstawiono rolę muzyki i jej wykonawców, a także oficjalnych mediów w rozpropagowaniu satanizmu, reakcje społeczne na jego pojawienie się i działania mające na celu jego zwalczanie. W oparciu o nowe, niewykorzystane dotychczas źródła, autor weryfikuje niektóre twierdzenia funkcjonujące w literaturze przedmiotu i stawia nowe pytania badawcze.

Abstract: This article presents the history of youth Satanism, which appeared in Poland in the early 1980s. It was brought up by the fashion for heavy metal music, and the formation of a youth subculture gathered around this music and its subgenres. First, the author outlines the cultural background of the emergence and development of contemporary Satanism in the USA and Western Europe. Next, he describes its reception in Poland of the eighties, which, on the one hand, took place in isolation from the American and Western European sources of this phenomenon, while, on the other, it was an attempt to copy it, under the conditions of a non-democratic and largely traditional society. He also presents the role of music and its performers, as well as that played by official media in propagating Satanism, together with social reactions to its appearance and activities aimed at combating it. Based on new, unused sources, the author verifies some claims formulated in the literature on the subject and poses further research questions.
\end{abstract}

Słowa kluczowe: satanizm, religie i wyznania w Polsce, nieformalne ruchy religijne, kontrkultura, heavy metal, subkultura metalowa, subkultura młodzieżowa, młodzież w PRL, lata osiemdziesiąte XX w.

Keywords: Satanism, religions and confessions in Poland, informal religious movements, counterculture, heavy metal, metal subculture, youth subculture, youth in People's Poland, 1980s 
Współczesny satanizm, będący fenomenem z pogranicza religii i kultury, nie jest szerzej obecny w polskiej humanistyce, a tym bardziej historiografii ${ }^{1}$. Większość opracowań i artykułów w języku polskim ukazała się w latach dziewięćdziesiątych XX w. i na początku XXI stulecia, a ich autorami byli religioznawcy, teolodzy, socjologowie, prawnicy i pedagodzy, którzy skupili się na analizie tego zagadnienia w oparciu o swoje warsztaty badawcze, w niewielkim stopniu starając się zrekonstruować moment jego pojawienia się i proces rozwoju w latach osiemdziesiątych $\mathrm{XX}$ w. ${ }^{2}$

W teologii chrześcijańskiej mianem satanizmu określa się różnorodne formy kultu Szatana, uważanego za istotę duchową, stworzoną przez Boga, która z własnej woli zerwała swój związek ze Stwórcą, stając się jego przeciwnikiem, a tym samym źródłem wszelkiego zła ${ }^{3}$. Potocznie za satanizm uważa się również wszelkie praktyki magiczne i kultowe, mające na celu uzyskanie wpływu na istoty uznawane $\mathrm{w}$ danej tradycji religijnej za negatywne i niebędące dozwolonym przedmiotem kultu. I choć wielu autorów korzeni satanizmu doszukuje się m.in. w wierzeniach i systemach religijnych kultur starożytnego Bliskiego Wschodu, gnostycyzmie, średniowiecznych herezjach czy mocno obecnej w średniowiecznej i nowożytnej Europie demonologii ludowej, wydaje się, że jego współczesne oblicze ma znacznie młodszą genezę, sięgającą co najwyżej antyoświeceniowego irracjonalizmu, romantycznego buntu przeciwko obowiązującym normom i modnych w XIX w. utworów frenetycznych. Do tego zestawu można jeszcze dodać fascynację elit okultyzmem w drugiej połowie XIX i na początku XX w., która w okresie międzywojennym znalazła odbicie w kulturze masowej ${ }^{4}$.

Na współczesny satanizm złożyły się różnorodne nurty i tradycje, tzw. lewej ścieżki („ścieżki lewej ręki”), do której w ezoteryce zachodniej, oprócz tradycyjnych form satanizmu (w sensie: kultu Szatana), zalicza się przede wszystkim: wicca, okultyzm, magię Aleistera Crowleya z jej konotacjami, pośrednio również neopogaństwo ${ }^{5}$.

\footnotetext{
${ }^{1} \mathrm{Na}$ zachodzie satanizm ma bogatą, wciąż powiększającą się literaturę. Do najważniejszych prac wydanych w ostatnich latach należą: M. Introvigne, Satanism. A Social History, Leiden-Boston 2016 (tegoż autora ukazało się w języku polskim: Satanizm. Historia, mity, Kraków 2014); R. van Luijk, Children of Lucifer. The Origins of Modern Religious Satanism, New York 2016; C. Mathews, Modern Satanism, Anatomy of a Radical Subculture, Westport 2009; J.R. Lewis, Satanism Today, Santa Barbara-Denver-Oxford 2001; C.H. Partridge, E.S. Christianson, The Lure of the Dark Side. Satan and Western Demonology in Popular Culture, New York 2014; A. Dyrendal, J.R. Lewis, J.A. Petersen, The Invention of Satanism, Oxford 2016.

2 Zob. bibliografię zamieszczoną na końcu niniejszego artykułu.

3 Analiza satanizmu z punktu widzenia teologii katolickiej, zob. A.J. Nowak OFM, Satanizm, w: Satanizm, rock, narkomania, seks, red. idem, Lublin 2001, s. 15-80; A. Zwoliński, Satanizm, Radom 2007.

${ }^{4}$ A. Sołtysiak, Satanizm tradycyjny, w: Religia. Encyklopedia PWN, t. 9, red. T. Gadacz, B. Milerski, Warszawa 2003, s. 44.

5 Z. Łagosz, A. Świerzowska, Ciemniejsza strona ciemności - ścieżka lewej ręki w zachodniej tradycji ezoterycznej. Wybrane zagadnienia, „Zeszyty Naukowe Uniwersytetu Jagiellońskiego. Studia Religiologica" 2015, nr 1, s. 89.
} 
Propagatorzy i wyznawcy współczesnego satanizmu odwołują się najczęściej do obecnych w kulturze zachodniej wyobrażeń dotyczących tradycyjnego satanizmu oraz szeroko pojętej tradycji okultystycznej. Przeważnie nie uznają przy tym istnienia żadnej istoty wyższej, a własne pragnienia i dążenia uważają za jedyne kryterium działania. Nie godzą się również na jakiekolwiek zewnętrzne ograniczenia moralne i kulturowe ${ }^{6}$. Rdzeniem ideologii propagowanej przez współczesne organizacje i związki satanistyczne oraz osoby deklarujące się jako sataniści są przede wszystkim: hedonizm (rozumiany jako zaspakajanie wszelkich pragnień), skrajny indywidualizm oraz przekonanie o nieorganicznych możliwościach człowieka, krępowanych jednak przez tradycyjne normy społeczne i obyczajowe, mające swoje źródło w religii, przede wszystkim w chrześcijaństwie. Współczesny satanizm jest tym samym formą buntu wobec zastanych norm, tradycji, wzorców społecznych i chrześcijaństwa. Na to wszystko nałożony został popkulturowy kostium, na który składają się rozmaite wyobrażenia Szatana, istot demonicznych oraz elementy tzw. wiedzy tajemnej. Jest zatem satanizm współczesny zjawiskiem niejednorodnym, amalgamatem różnych tradycji i elementów ${ }^{7}$.

W literaturze przedmiotu podkreśla się często antychrześcijański (w Polsce przede wszystkim antykatolicki) i aspołeczny charakter satanizmu, którego przyczyną ma być rzekoma akceptacja zła jako głównej zasady działania ${ }^{8}$. Włoski antropolog i historyk religii Alfonso Maria di Nola uważał, że za zjawiskiem satanizmu stoją ,ideologiczne potencjały wywrotowe, gwałtownie krytyczne wobec naszych społeczeństw. Potencjały te przybierają formy pragnące odgrywać rolę negacji struktur i afirmowania jako wartości elementów, które w tych strukturach uważane są za antywartości (przemoc, seks, absolutna swoboda życia seksualnego, niemoralność itd.)"9.

Piotr Stawiński zaproponował trójpoziomową klasyfikację współczesnego satanizmu, który podzielił na jawnie zorganizowany, subkulturowy i domniemanie zorganizowany. Pierwszy poziom to zarejestrowane i działające zgodnie z obowiązującym w danym kraju prawem organizacje religijne lub stowarzyszenia głoszące szeroko rozumianą ideologię satanistyczną. Drugi jest ściśle związany z kulturą popularną i składają się nań elementy przekonań i obyczajowości występujące głównie wśród młodzieży (muzyka, strój, symbolika itp.). Trzeci poziom to tzw. mit satanistyczny, na który składa się przede wszystkim przekonanie o istnieniu ogólnoświatowej, świetnie zorganizowanej, konspiracyjnej struktury, obecnej na

\footnotetext{
${ }^{6}$ A. Sołtysiak, Satanizm współczesny, w: Religia. Encyklopedia..., t. 9, s. 44.

7 P. Szarszewski, Satanizm w Polsce Próba analizy zjawiska, Warszawa 2004; A. Sołtysiak, Satanizm współczesny, „Antropologia Religii” 5, 2013, s. 86; Z. Łagosz, A. Świerzowska, op. cit., s. 95.

8 P. Szarszewski, op. cit.

9 A.M. di Nola, Diabeł. O formach, historii i kolejach losu Szatana, a także o jego powszechnej a złowrogiej obecności wśród wszystkich ludów, od czasów starożytnych aż po teraźniejszość, Kraków 1997, s. 236.
} 
wszystkich szczeblach drabiny społecznej, odpowiedzialnej za niezliczone morderstwa kultowe, rytualną przemoc seksualną oraz inne, odrażające nadużycia wobec ludzi i zwierzą ${ }^{10}$.

Pomimo tych prób typologii i klasyfikacji, większość autorów zgodna jest co do trudności w takim zdefiniowaniu pojęć „satanizmu” i „satanisty”, które byłyby użyteczne w naukach społecznych i humanistycznych. Tym bardziej że, jak zauważył Jacek Sieradzan, „w praktyce do worka z napisem «satanizm» wrzuca się wszystko: od ruchów neopogańskich, poprzez New Age, a skończywszy na muzyce pop (The Beatels)"11. Przywołany już wcześniej Piotr Stawiński uważa, że satanizm najprościej zdefiniować jako adorację Szatana lub innej postaci demonologii chrześcijańskiej. Jednocześnie przyznaje, że jest to definicja mało precyzyjna, pomimo to wystarczająca do opisu tego zjawiska. Zgodnie z nią, twierdzi Stawiński, „żeby być satanistą, trzeba znać religię chrześcijańską i zaprzeczając jej podstawowemu przesłaniu o prymacie Boga, będącego uosobieniem Dobra i Porządku, opowiedzieć się za siłami Zła i Chaosu. Stać intelektualnie i emocjonalnie w ostrej opozycji wobec chrześcijaństwa, jego wartości i cnót"12.

Arkadiusz Sołtysiak, który również zwraca uwagę na problemy nastręczane przez próbę zdefiniowania współczesnego satanizmu, postuluje przyjęcie jako jedynego kryterium definicyjnego samą nazwę. Tym samym satanistą jest każdy, kto sam siebie określa takim mianem, niezależnie od wyznawanych poglądów, wiedzy na temat satanizmu, przynależności instytucjonalnej czy wspólnotowej oraz uczestnictwa w praktykach kultowych. I choć autor tej definicji przyznaje, że jest „mało wyszukana”, to jednocześnie podkreśla jej jednoznaczność i bezdyskusyjność oraz przydatność metodologiczną ${ }^{13}$. Jest ona również użyteczna dla rozważań w niniejszym studium, choć należy w tym miejscu podkreślić, iż jest niewyczerpująca oraz kryje pułapkę polegającą na określaniu się jako satanista bądź odżegnywaniu od tego miana w zależności od kontekstu czy sytuacji. I tak niejednokrotnie młodzi ludzie zapytani przez rodziców czy wychowawców zaprzeczali, że są satanistami, choć twierdzili tak przed rówieśnikami. Podobnie muzycy z zespołów wykonujących utwory czerpiące z mitu satanistycznego inny przekaz kierowali do fanów i słuchaczy, inny zaś do mediów, zwłaszcza kiedy ich

10 P. Stawiński, Współczesny mit miejski. Uwagi na temat kształtowania się i społecznego funkcjonowania stereotypu satanisty, „Przegląd Religioznawczy” 1997, nr 4, s. 156; idem, Społeczny odbiór satanizmu. Źródła i dynamika przekonań na przykładzie Stanów Zjednoczonych lat 80., „Państwo i Społeczeństwo" 8, 2008, nr 1, s. 152.

${ }^{11} \mathrm{~J}$. Sieradzan, W kręgu pojęć: ezoteryzm, okultyzm, satanizm, w: Ezoteryzm, okultyzm, satanizm $w$ Polsce, red. Z. Pasek, Kraków 2005, s. 243. O etymologii terminu „satanizm” i kogo uważano za satanistów zob. ibidem, s. 236-243.

12 P. Stawiński, Współczesny mit miejski ..., s. 155-156.

13 A. Sołtysiak, Współczesny satanizm. Krótki przegląd głównych nurtów i ideologii, „Przegląd Religioznawczy" 2011, nr 2, s. 163-164. 
działalność artystyczna zaczęła być kojarzona z przestępstwami czy wykroczeniami popełnianymi przez fanów.

Czym zatem był satanizm młodzieżowy w Polsce lat osiemdziesiątych XX w.? Przede wszystkim formą buntu przeciwko światu dorosłych, ich kulturze, religii, tradycji, obyczajom i wszystkiemu, co składało się na tradycyjne wzorce społeczno-kulturowe, zwłaszcza te mocno osadzone w kontekstach chrześcijańskich, głównie katolickich. Antychrześcijańskość (antykatolickość) była ideową osią tego buntu, który wyrażał się m.in. w formach ekspresji artystycznej charakterystycznych dla ówczesnej kultury masowej, przede wszystkim w muzyce rockowej. Satanistami były tym samym osoby utożsamiające się z antychrześcijańskim buntem, wyrażanym szczególnie za pomocą sztuki (głównie muzyki), w której bezpośrednio lub pośrednio odnoszono się do postaci Szatana lub innych istot demonicznych i postaci nadprzyrodzonych z szerokiego spektrum wyznań i religii stojących w opozycji do chrześcijaństwa. Byli to przeważnie ludzie młodzi, w okresie adolescencji lub na progu dorosłości, kiedy system wyznawanych i werbalnie deklarowanych wartości najczęściej nie jest spójny. Jednym z głównym źródeł ich światopoglądu były teksty kultury masowej: słowa piosenek rockowych, wypowiedzi idoli (muzyków), literatura popularna, filmy fabularne, reportaże, publicystyka. $Z$ racji silnego związku satanizmu młodzieżowego z kulturą muzyczną, przede wszystkim heavy metalem, przybierał on postać subkultury w formie zewnętrznej niewiele lub w ogóle nieróżniącej się od tzw. subkultur metalowych, co było często i jest do dziś przyczyną licznych pomyłek i błędów, zarówno w publicystyce, jak i opracowaniach naukowych. Grupy satanistów nie były zorganizowane i nie tworzyły żadnej większej struktury organizacyjnej. Rytuały, jeśli w ogóle się pojawiały, nie były usystematyzowane i najczęściej nie miały podstaw teoretycznych ${ }^{14}$.

Ów młodzieżowy satanizm, który w latach osiemdziesiątych pojawił się nad Wisłą, był jednym z elementów kultury popularnej, a jego genezy należy szukać w kulturowych przeobrażaniach zachodniej cywilizacji w drugiej połowie XX w.

W 1966 r. w San Francisco trzydziestosześcioletni wówczas Howard Stanton Levey, od młodości interesujący się magią, okultyzmem i zjawiskami paranormalnymi, powołał do istnienia Kościół Szatana. Skupił wokół siebie grupę osób o podobnych poglądach i zainteresowanych, a sam ogłosił się najwyższym kapłanem („czarnym papieżem”) i przybrał pseudonim Anton Szandor LaVey. Stworzył mit własnej osoby i sfałszował swój życiorys, dopisując doń wydarzenia, które w rzeczywistości nie miały miejsca, a inne fakty przeinaczając. Umiejętnie wykreował się na bohatera kultury masowej, a kreacja ta wpisała się w kontrkulturowy obraz ówczesnej Ameryki. Do grupy liczącej początkowo około dwudziestu

14 I. Christiansen, Satanizm w Europie - aktualny stan stosowanych działań profilaktycznych, w: Satanizm w Polsce i Europie. Stan obecny i profilaktyka, red. G. Fels, Ruda Śląska 2004, s. 62-63. 
osób z czasem dołączyli kolejni wyznawcy, wśród których, obok snobizujących się na bohemę lekarzy czy prawników, znaleźli się różnego autoramentu outsiderzy, pisarze science fiction, autorzy horrorów i dziennikarze. Ci ostatni zapewnili przedsięwzięciu LaVeya sukces medialny. Kościół Szatana uzyskał w Kalifornii status zarejestrowanego związku wyznaniowego, nie stał się jednak masową organizacją religijną. W okresie największego rozkwitu, w latach 1969-1975, liczba zarejestrowanych członków liczyła około 250 osób oraz kilka tysięcy sympatyków. Pomimo to LaVey potrafił na tyle wystarczająco przyciągnąć zainteresowanie mediów i części środowiska artystycznego, by zapewnić kierowanemu przez siebie kościołowi popularność, a co za tym idzie również niezłe dochody. Reportażami dotyczącymi „czarnego papieża”, a zwłaszcza opisami sprawowanych przez niego satanistycznych rytuałów karmiła się przede wszystkim prasa brukowa oraz szukający sensacji telewizyjni reporterzy. W latach sześćdziesiątych i siedemdziesiątych XX w. Kościół Szatana stał się tematem książek, reportaży, artykułów prasowych i filmów, w których fakty często przeplatały się z nieprawdziwymi opisami rzekomych mordów rytualnych, orgii seksualnych i czynów powszechnie odbieranych jako sprzeczne $\mathrm{z}$ akceptowalnymi społecznie zasadami. Pomimo że w następnych latach niektórzy z wyznawców Kościoła Szatana odeszli od LaVeya i założyli własne wspólnoty, jak również pojawiły się inne, niezwiązane z Kościołem Szatana grupy satanistyczne, to bez wątpienia właśnie tzw. satanizm laveylański przeniknął najmocniej do kultury popularnej ${ }^{15}$.

LaVey opracował doktrynę kościoła, efekt jego wcześniejszych lektur i przemyśleń, będącą połączeniem ateizmu i materializmu $\mathrm{z}$ hedonizmem i skrajnym indywidualizmem. Opublikował pięć książek, z których pierwsza, zatytułowana Biblia Szatańska (The Satanic Bible, 1969, w Polsce wydana jako Biblia Szatana) stała się bestsellerem i została przetłumaczona na kilkanaście języków ${ }^{16}$. Ideologię satanizmu laveylańskiego można sprowadzić do kilku punktów. Po pierwsze ateizmu, polegającego na odrzuceniu a priori możliwości istnienia jakiejkolwiek formy transcendencji. Po drugie egoizmu, wynikającego z rzekomo egocentrycznej, zwierzęcej natury człowieka. Po trzecie prawa do zemsty, często mylnie interpretowanego jako nakazu czynienia zła. I wreszcie po czwarte permisywnego podejścia do seksu, jeżeli tylko nie wyrządza się tym komuś krzywdy, co można zinterpretować jako przyzwolenie na wszelkie praktyki seksualne pod warunkiem, że dobrowolnie godzą się na nie ich uczestnicy. Realizacja tych postulatów ma zapewnić człowiekowi szczęście i prawdziwą, gdyż nieskrępowaną żadnymi

15 A. Sołtysiak, Satanizm współczesny, „Antropologia Religii”..., s. 90-91; idem, Satanizm wspótczesny, w: Religia. Encyklopedia..., s. 44.

16 Pierwsze, oficjalne polskie tłumaczenie pt. Biblia Szatana ukazało się w 1996 r. we Wrocławiu nakładem Wydawnictwa Książki Niezwykłej „Mania”. Rok wcześniej Roman Kostrzewski nagrał recytacje fragmentów książki La Veya z podkładem muzycznym, które ukazały się dwóch kasetach magnetofonowych. 
ograniczeniami, wolność. Istotę satanizmu zaproponowanego przez LaVeya można streścić w stwierdzeniu: religia chrześcijańska i czerpiąca zeń kultura narzuciły wstrzemięźliwość i kontrolę naturalnych instynktów, co sprawia, że ludzie stali się nieszczęśliwi. Dlatego, żeby być szczęśliwym, należy odrzucić chrześcijański system norm i wartości. Należy cieszyć się życiem, starać się nie krzywdzić innych, ale też nie dać się skrzywdzić, bez skrępowania realizować swoje zachcianki, również te najbardziej perwersyjne i nie pozwolić, aby jakakolwiek religia ograniczała indywidualną wolnośćc ${ }^{17}$.

Postawy hedonistyczne, relatywizm etyczny i niechęć do chrześcijaństwa, ubrane w eklektyczny kostium ceremonialnej magii i popularnych wyobrażeń o naukach i obrzędach tajemnych spowodowały, że Kościół Szatana na dobre zaistniał w amerykańskiej, a następnie zachodnioeuropejskiej popkulturze, do czego przyczyniła się spora popularność LaVeya i jego poglądów wśród artystów i muzyków rockowych. W 1975 r. w Kościele Szatana doszło do rozłamu, wskutek którego wyodrębniła się Świątynia Seta. Jej twórcy zarzucili „czarnemu papieżowi” komercjalizację i sprowadzenie satanizmu do poziomu kulturowej mody. Nie udało im się jednak przebić popularnością laveyańskiej wersji satanizmu ${ }^{18}$.

W następnych latach w USA i Europie Zachodniej powstały setki mniejszych grup i organizacji satanistycznych lub w jakiejś części wykorzystujących mit satanistyczny. Ich działalność, często koloryzowana i wyolbrzymiana, rozpropagowana przez media, była przedmiotem zainteresowania policji, wymiaru sprawiedliwości i środowisk psychologiczno-terapeutycznych. Informacje o rzekomych przestępstwach i zbrodniach rytualnych stały u podstaw tzw. histerii satanistycznej (określanej również mianem paniki satanistycznej), nieadekwatnej do rzeczywistej skali tych zjawisk ${ }^{19}$.

Z satanizmu, okraszonego elementami wywodzącymi się z tradycji okultystycznej i teozofii, zaczęła w tym samym czasie obficie czerpać kultura popularna, zwłaszcza muzyka, a przede wszystkim rock. Satanistyczne wątki w muzyce popularnej mają obfitą literaturę, wśród której nie brakuje często fantastycznych teorii. Pomijając spekulacje dotyczące rzekomo satanicznej twórczości większości zespołów rockowych czy twierdzeń doszukujących się satanizmu w utworach Elvisa Presleya czy The Beatles, bez wątpienia grupą, która wprowadziła elementy satanistyczne do swojej twórczości, był Black Sabbath. W 1969 r. zespół zarejestrował debiutancki krążek, którego premiera odbyła się w piątek 13 lutego 1970 r. Album ten, zarówno pod względem muzyki, tekstów utworów,

17 P. Szarszewski, op. cit., s. 31; A. Sołtysiak, Wspótczesny satanizm..., s. 166-168.

18 D. Misiunia, „Człowiek stwarza samego siebie”, czyli o okultystycznym projekcie antropologicznym, w: Ezoteryzm, okultyzm..., s. 57.

19 A. Sołtysiak, Satanizm współczesny, „Antropologia Religii”..., s. 93; idem, Współczesny satanizm..., s. 171; P. Stawiński, Społeczny odbiór satanizmu..., s. 151. 
jak i oprawy plastycznej (okładkę zdobił odwrócony krzyż), miał bezsprzecznie kolosalny wpływ na estetykę heavy metalu. Również w 1969 r. debiutancką płytę pt. „Witchcraft Destroys Minds \& Reaps Souls” nagrała amerykańska formacja Coven. Na fotografii umieszczonej na okładce również widniał odwrócony krzyż i gest ręki z dłonią, której palce ułożone były w „diabelskie rogi” - gest dziś wykorzystywany w kulturze masowej, często w oderwaniu od satanistycznego pierwowzoru. W ciągu dekady lat siedemdziesiątych ukształtowała się heavymetalowa estetyka, której elementy są obecne również i dzisiaj wśród zespołów wywodzących się z lub nawiązujących do tego nurtu ${ }^{20}$. W pierwszej połowie lat osiemdziesiątych do czołówki wykonawców mocno osadzonych w satanistycznej symbolice zaliczano brytyjski Venom. Ich debiutancki album, który ujrzał światło dzienne w 1981 r., nosił tytuł „Welcome To Hell”. Zarówno pseudonimy wykonawców, jak i teksty oraz oprawa plastyczna płyty świadczyły o fascynacji muzyków twórczością LaVeya. Okładkę zdobiła tzw. pieczęć Bafometa zaczerpnięta z wydawnictw sygnowanych przez laveylański Kościół Szatana, muzycy zaś otwarcie przyznawali się do bycia satanistami ${ }^{21}$. Pomimo to lider zespołu zarzekał się, że „wcale nie głosimy satanizmu, po prostu piszemy fikcyjne rock'n'rollowe teksty o antychrześcijaństwie, teksty, które celowo napawają trwogą ignorantów"22. Venom uważany jest za jeden $\mathrm{z}$ zespołów, który zainicjował podgatunek heavy metalu zwany black metalem, uważany za artystyczną formę kultowego satanizmu²3.

Do podobnych inspiracji przyznawali się także inni muzycy tworzący w obrębie metalu, jak chociażby pochodzący z Danii Kim Bendix Petersen (występujący pod pseudonimem artystycznym King Diamond), frontman zespołu Mercyful Fate, który osobiście odwiedził LaVeya w San Francisco i został oficjalnym członkiem jego Kościoła ${ }^{24}$. Dayal Patterson, autor monografii black metalu stwierdza: „Choć nie ulega wątpliwości, że [King] Diamond rozdzielał sferę własnych przekonań od bardziej tradycyjnego, utrzymanego w stylu grozy, chrześcijańskiego pojmowania satanizmu, którym charakteryzowały się utwory Mercyful Fate, prawdopodobne, iż wiele $\mathrm{z}$ tych subtelności umknęło uwadze ówczesnych fanów zespołu. Istnienie zespołu utrzymującego związek z bezbożną materią, którą zajmował się we własnej twórczości, przydało gatunkowi autentyczności, będąc zarazem oczywistym paliwem dla postaw przyjętych przez wiele przyszłych formacji. Granica została wyznaczona; od tej chwili istniały zespoły, które wierzyły i praktykowały satanizm, oraz te, które jedynie o nim śpiewały"25. To właśnie za pośrednictwem muzyki

20 D. Patterson, Black Metal. Ewolucja kultu, Poznań 2016, s. 1-3.

${ }^{21}$ Ibidem, s. 6-11; P. Czarnecki, Koncepcja satanizmu w drugiej fali Black Metalu, w: Kultura metalowa w przestrzeni rytualnej i medialnej, red. J. Kosek, Kraków 2019, s. 7.

22 Cyt. za D. Patterson, op. cit., s. 11.

23 I. Christiansen, op. cit., s. 63-69.

${ }^{24}$ P. Czarnecki, op. cit., s. 7.

25 D. Patterson, op. cit., s. 20. 
mit satanistyczny, będący inspiracją dla wielu muzyków przede wszystkim, tworzących w różnych nurtach heavy metalu, rozpowszechnił się wśród młodzieży i stał się jednym $\mathrm{z}$ wyrazów buntu nastolatków przeciwko światu ${ }^{26}$.

Ciężki rock i jego następca heavy metal miał w Polsce lat siedemdziesiątych XX w. zwiększające się z roku na rok grono fanów, jednak niewielu rodzimych wykonawców. $W$ drugiej połowie dekady niektóre zespoły, jak np. założony w 1977 r. w Warszawie zespół Zjednoczone Siły Natury Mech (później używający skróconej nazwy Mech), zaczęly czerpać z metalowej estetyki. Przełomem było pojawienie się na polskiej scenie muzycznej grupy TSA, uznawanej za pierwszy polski zespół stricte heavymetalowy. Założony w 1979 r. w Opolu, zdobył nagrodę publiczności podczas II Ogólnopolskiego Przeglądu Muzyki Młodej Generacji w 1981 r. w Jarocinie. W tym samym roku ukazał się ich pierwszy singiel, a dwa lata później debiutancki album wydany nakładem wydawnictwa płytowego Tonpress. Członkowie TSA jako pierwsi użyli słów „heavy metal” do określenia wykonywanej przez nich muzyki ${ }^{27}$.

Twórczość TSA, choć mocno osadzona w metalowej stylistyce, nie sięgała po treści czy motywy sataniczne. Co innego powstały na przełomie 1979 i 1980 r. w Katowicach zespół Kat. Grupa początkowo wykonywała muzykę instrumentalną. W 1981 r. dołączył do niej wokalista Roman Kostrzewski. Trzy lata później, jesienią 1984 r. nagrany został debiutancki singiel z utworami Ostatni tabor i Noce Szatana, który na rynku pojawił się na początku 1985 r. W tym samym roku zespół został entuzjastycznie przyjęty na festiwalu w Jarocinie. W 1986 r. dla belgijskiej wytwórni muzycznej Ambush Records zespół nagrał angielskojęzyczną płytę pt. „Metal and Hell”, która w następnym roku została wydana w Polsce przez wytwórnię Pronit. Polskojęzyczna wersja albumu z tytułem zmienionym na „666” ukazała się w maju 1986 r. na płycie winylowej wydanej w ograniczonym, pięciotysięcznym nakładzie przez Klub Płytowy „Razem” oraz na kasecie wydanej przez wydawnictwo Polmark w nakładzie 20 tys. egzemplarzy. Autorem większości tekstów był Roman Kostrzewski. Również w 1986 r. ukazała się płyta „Kawaleria szatana" założonej w 1980 r. formacji Turbo, która w pierwszej połowie dekady przeszła ewolucję od hard rocka do thrash metalu ${ }^{28}$.

TSA, Kat i Turbo, pomimo dzielących te zespołu różnic stylistycznych, zostały ochrzczone mianem tzw. wielkiej trójcy polskiego metalu, stanowiąc rdzeń pierwszej fali tego nurtu muzyki w Polsce. Zespoły te w latach osiemdziesiątych miały nie tylko szerokie grono fanów, ale również znalazły licznych naśladowców.

\footnotetext{
26 A. Sołtysiak, Wspótczesny satanizm..., s. 171-172.

27 R. Wolański, Leksykon polskiej muzyki rozrywkowej, t. 2, Warszawa 2003, s. 176-177; M. Kopiński, Idea wolności w tekstach piosenek heavymetalowych lat 80. w twórczości TSA, Turbo i KAT, „Kwartalnik Młodych Muzykologów UJ” 2015, nr 4, s. 71.

${ }^{28}$ R. Wolański, op. cit., t. 3, s. 289; F. Bogaczyk, Zetrzyj krew i graj dalej. Historia zespolu Turbo, Poznań 2019.
} 
Wykonawcy różnych odmian metalu przez całą dekadę lat osiemdziesiątych byli obecni na festiwalach w Jarocinie.

W początkowym okresie rozkwitu metalu w Polsce, jak słusznie zauważył Maciej Kopiński, „ograniczenia sprzętowe, niedostatki umiejętności komponowania czy warunki wydawnicze, a właściwie ich brak w PRL, siłą rzeczy powodowały opóźnienie w stosunku do Zachodu. Oprócz wymienionych grup, istotny wpływ na rozwój i kształtowanie metalu w Polsce miały zespoły, które osiągnęły mniejszy sukces komercyjny bądź nie osiągnęły go w ogóle i tworzyły tzw. scenę podziemną. W większości opierały swoją muzykę na wzorcach z Zachodu, niektóre prezentowały niski poziom techniczny, ale poprzez udział w koncertach, przeglądach czy festiwalach propagowały muzykę metalową i wśród młodych słuchaczy były alternatywą dla rocka i punku. Polską scenę metalową tworzyło kilkadziesiąt zespołów. Wynik ten związany jest z tym, że słuchacze muzyki metalowej, w dużej mierze młodzi ludzie, nie pozostawali tylko i wyłącznie fanami, ale sami pod wpływem innych grup zakładali zespoły, chcąc aktywnie tworzyć scenę metalową w kraju"29.

Podobnie jak na zachodzie Europy, również i w Polsce heavy metal miał swoich fanów przeważnie w dużych aglomeracjach miejskich. Analogicznie do Wielkiej Brytanii czy Republiki Federalnej Niemiec najwięcej twórców i odbiorców tego gatunku mieszkało na terenach silnie uprzemysłowionych i zurbanizowanych. Spora część polskich zespołów heavymetalowych, tworzących w latach osiemdziesiątych tzw. scenę podziemną, powstała na terenie ówczesnego województwa katowickiego. W 1986 r. w hali widowiskowo-sportowej Spodek w Katowicach odbyła się pierwsza edycja Metalmanii - festiwalu muzyki metalowej, który z czasem stał się największym, corocznym przeglądem tego rodzaju wykonawców w Europie. Katowice w drugiej połowie lat osiemdziesiątych określano mianem „metalowej stolicy Polski”30. „Pierwsze kontakty z respondentami nawiązałam przed koncertami rockowymi - głównie w Katowicach", stwierdziła badaczka satanizmu młodzieżowego, która na przełomie lat osiemdziesiątych i dziewięćdziesiątych zbierała materiały do swojej pracy ${ }^{31}$. Heavy metal, a mówiąc szerzej po prostu metal, w latach osiemdziesiątych zyskał w aglomeracji katowickiej tylu fanów, że na długowłosego mężczyznę ubranego na czarno, w wąskich spodniach i skórzanej kurtce lub dżinsowej bluzie mówiono w innych częściach kraju „śląski metal”32.

\footnotetext{
${ }^{29}$ M. Kopiński, op. cit., s. 72.

${ }^{30}$ Ibidem, s. 73.

31 B. Hoffmann, Satanizm polski - mit czy rzeczywistość?, Warszawa 1991, s. 6.

32 B. Tracz, Śląski blues czy śląski metal?, „CzasyPismo” 2014, nr 1, s. 36-41. Notabene województwo katowickie było w latach osiemdziesiątych obszarem intensywnego rozwoju i działalności wszystkich subkultur młodzieżowych. Na festiwalu w Jarocinie jego mieszkańcy stanowili największą regionalną grupę uczestników, wahającą się w latach 1986-1988 pomiędzy 10 a 12\%, wyprzedzając dwu-, a nawet trzykrotnie województwa stołeczne warszawskie, wrocławskie czy szczecińskie.
} 
Satanizm młodzieżowy, który pojawił się w Polsce we wczesnych latach osiemdziesiątych XX w., był zatem związany z przenikaniem nad Wisłę twórczości zachodnich, przede wszystkim amerykańskich, brytyjskich i zachodnioniemieckich zespołów i muzyków rockowych, grających różne odmiany heavy metalu, wykorzystujących i eksponujących wątki ezoteryczne i mit satanistyczny oraz często deklarujących się jako sataniści, najczęściej nawiązując do satanizmu laveylańskiego ${ }^{33}$. Jak słusznie skonstatowała Anna Mikołejko, „młodzieżowy satanizm w Polsce nie jest bowiem związany z tradycją rodzimą - ani z tą elitarną, literacką, ani z demonologią ludową" ${ }^{34}$. Nie zmienia to faktu, że w wywiadach czy wspomnieniach, które ukazały się już po 1990 r., artyści wykorzystujący w swej twórczości motywy i wątki satanistyczne mówili o inspiracjach i nawiązaniach do twórczości takich autorów jak np. Stanisław Przybyszewski czy Tadeusz Miciński. Wydaje się jednak, że te rodzime wątki były wtórne względem mody na satanizm, której rozsadnikiem była przede wszystkim twórczość zachodnich wykonawców heavy metalu ${ }^{35}$.

Jako wydarzenie inicjujące zjawisko młodzieżowego satanizmu w Polsce uznaje się najczęściej rok 1981, kiedy to do zespołu Kat dołączył Roman Kostrzewski. Część autorów właśnie w nim widzi osobę odpowiedzialną za rozpropagowanie mody na satanizm, czego on sam ani nie potwierdzał, ani czemu nie zaprze$\mathrm{cza}^{36}$. W moim przekonaniu przypisywanie Kostrzewskiemu tak silnej, czasami niemal wyłącznej roli kulturotwórczej jest nieco na wyrost. Na pewno początek lat osiemdziesiątych, a zwłaszcza piętnaście miesięcy pomiędzy sierpniem 1980 a grudniem 1981 r., określanie jako tzw. karnawał Solidarności, to okres fermentu w kulturze popularnej nad Wisłą. Jednym $\mathrm{z}$ aspektów kulturowego ożywienia było powstanie wielu, profesjonalnych i amatorskich, grup muzycznych wykonujących różne odmiany rocka i muzyki rozrywkowej, w tym tych do tej pory prawie nieobecnych na rodzimych scenach, jak punk rock, new wave, reggae czy różne odmiany heavy metalu. Wprowadzenie stanu wojennego na krótko zdusiło instytucjonalne formy twórczości artystycznej, lecz bynajmniej nie zatrzymało zmian w tej przestrzeni kultury, którą określano mianem „młodzieżowej”. Pierwsza

Również największy procent zespołów i wykonawców wywodził się z województwa katowickiego (12,1\% w 1987 r., 7,7\% w 1988 r.), R. Matykowski, E. Figisiak, Społeczne i przestrzenne aspekty oddziaływania festiwalu muzyki rockowej w Jarocinie, w: Dźwięk w krajobrazie jako przedmiot badań interdyscyplinarnych, red. S. Bernat, Lublin 2008, s. 278-279.

33 P. Szarszewski, op. cit., s. 20-21.

34 A. Mikołejko, Polski satanizm młodzieżowy, „Przegląd Religioznawczy” 1992, nr 1, s. 124.

35 O młodzieńczej fascynacji poezją Tadeusza Micińskiego lider zespołu Kat Roman Kostrzewski opowiedział w wywiadzie-rzece, który przeprowadził z nim Mateusz Żyła, R. Kostrzewski, M. Żyła, Roman Kostrzewski. Głos z ciemności, Kraków 2016, s. 96-98.

36 W obszernym wywiadzie wydanym drukiem w $2016 \mathrm{r}$. kwestia oskarżeń o propagowanie satanizmu i w ogóle wątki satanistyczne w jego biografii przedstawione zostały bardzo oględnie, biorąc pod uwagę wcześniejsze wypowiedzi Kostrzewskiego w mediach i recepcję jego twórczości w latach osiemdziesiątych, ibidem, passim. 
połowa lat osiemdziesiątych była w Polsce czasem krystalizowania się większości subkultur młodzieżowych, które rozwinęły się w pełni w drugiej połowie dekady, a ich członkowie znajdą naśladowców w kolejnym pokoleniu, już po upadku komunizmu. Jedną z nich była subkultura fanów heavy metalu, zwana najczęściej subkulturą metalowców. To właśnie na jej obrzeżach wykiełkował satanizm młodzieżowy, będący rodzimą kalką zjawiska już od kilkunastu lat mocno obecnego w zachodniej kulturze masowej. Była zatem pierwsza połowa lat osiemdziesiątych okresem osmozy, podskórnego przenikania idei satanistycznych z Zachodu do Polski, najczęściej, jeśli nie wyłącznie, w kontekście muzyki heavymetalowej. Była to, jak wiele podobnych zjawisk w tym czasie, recepcja często chaotyczna i wybiórcza, za którą nie stały próby tworzenia jakichkolwiek oficjalnych struktur, grup programowych czy formułowania ideologii ${ }^{37}$.

Jak w przypadku większości zjawisk kulturowych, trudno jest określić dokładnie „punkt zero". Na podstawie analizy informacji pochodzących z materiałów Komendy Głównej MO sierżant Grzegorz Banaszewski stwierdził, że pojawienie się w Polsce satanistów miało miejsce na przełomie 1983 i $1984 \mathrm{rr}^{38}$ Od $1984 \mathrm{r}$. w prasie zaczęły coraz częściej pojawiać się wzmianki o muzyce określanej mianem „satanistycznej” oraz jej fanach. Media, najczęściej w formie sensacji, informowały o działalności satanistów w Europie Zachodniej i w USA ${ }^{39}$. W tym samym roku zespół Kat zadebiutował przed ogólnopolską publicznością na Festiwalu Muzyków Rockowych w Jarocinie, stając się szybko jednym z najbardziej rozpoznawalnych wykonawców muzyki heavymetalowej w Polsce, a jednocześnie jednym z niewielu zespołów, które w swojej twórczości odwoływały się do satanizmu. W następnych latach zespół był najpopularniejszą rodzimą grupą, do której słuchania przyznawały się osoby mówiące o sobie, że są satanistami, a utwór pt. 666 z refrenem „Szatan, Szatan! z nim konać, nawet żyć” uważany był za nieformalny hymn tej społeczności ${ }^{40}$. Roman Kostrzewski tak tłumaczył noszenie przez niego naszyjnika z odwróconym krzyżem: „Proszę księdza, w XX w. to właściwie potrzeba ludziom zupełnie nowej doktryny, szczególnie młodym ludziom. Doktryny, która by docierała do ich podstaw, które są dla nich naturalne, nie takich które Kościół narzucił przez lata. Jest to niezgodne z moim duchem. Odwrócony krzyż świadczy o tym, że z tymi doktrynami się w ogóle nie zgadzam"41. Postawa Kostrzewskiego

37 A. Mikołejko, op. cit., s. 127.

38 AIPN, 001708/4047, G. Banaszewski, Działalność młodzieżowych grup satanistów w Polsce w latach 1986-1988, praca dyplomowa, ASW, Legionowo 1990, s. 24.

39 B. Hoffmann, op. cit., s. 1; AIPN, 001708/2919, J. Krobski, Nieformalne ruchy młodzieżowe - charakterystyka, tendencje rozwojowe, zagrożenia. Na podstawie materiałów operacyjnych uzyskanych $w$ trakcie zabezpieczenia Festiwalu Muzyków Rockowych Jarocin'86, praca dyplomowa, WSO MSW, Legionowo 1987, s. 28.

40 P. Szarszewski, op. cit., s. 37-38; A. Sołtysiak, Wspótczesny satanizm..., s. 171.

${ }^{41}$ Cyt. za: M. Kopiński, op. cit., s. 71-73. 
i jego poglądy znajdowały naśladowców, tym bardziej że wpisywały się w buntowniczą narrację sceny heavymetalowej. Moda na satanizm w połowie dekady była już faktem.

W dniach 4-5 kwietnia 1986 r. w katowickim Spodku odbyła się wspomniana wcześniej I edycja festiwalu Metalmania. Kat występował drugiego dnia w charakterze gwiazdy. Elementem koncertu grupy było przedstawienie, podczas którego półnaga dziewczyna podała wokaliście kielich z czerwonym płynem imitującym krew, a tancerki ucharakteryzowane na czarownice tańczyły w rytm muzyki Modesta Musorgskiego. Niektórzy widzieli w tym show elementy czarnej mszy ${ }^{42}$. Lider zespołu Roman Kostrzewski w wywiadzie telewizyjnym stwierdził: „Dla mnie koncert jest też rodzajem Czarnej Mszy - daje rozkosz traconej energii, bezpośredni kontakt $\mathrm{z}$ fanami, pieniądze... Ten wrzask, skakanie, pokazywanie się w metalowych strojach. Ci którzy przychodzą na koncerty, są młodzi - muszą się z czymś utożsamiać, te odwrócone krzyże, ćwieki, kozły, i co tam jeszcze, służą identyfikacji, tworzą wspólnotę" ${ }^{43}$. Było to jedynie potwierdzenie faktu obecnego w części muzyki heavymetalowej, która, przekraczając swój estetyczny wymiar, stawała się nośnikiem norm, obyczajowości i wierzeń, tworząc podczas koncertów rodzaj efemerycznego kultu religijnego, w którym słuchacze pełnią rolę „wyznawców”, a muzycy są „kapłanami”"4.

O ile występ Kata podczas Metalmanii w kwietniu 1986 r. można jeszcze zakwalifikować do czerpiącej z mitu satanistycznego ekspresji artystycznej, o tyle nie było nią już z pewnością wydarzenie, do którego doszło 26 czerwca tego samego roku w zrujnowanej i opuszczonej Wieży Bismarcka ${ }^{45}$ w Szczecinie. Szczecińska „czarna msza” odprawiona została ponoć przez trzy osoby, a jej datę wybrano nieprzypadkowo, gdyż dzień, miesiąc i rok zwierały w sobie szóstkę, a trzy szóstki to liczba apokaliptycznej bestii ${ }^{46}$. Jeden z jej uczestników kilka tygodni później był jedynym $\mathrm{z}$ inicjatorów podobnego rytuału, który odprawiony został w Jarocinie, o czym będzie jeszcze mowa.

W 1986 r. Festiwal Muzyków Rockowych w Jarocinie rozpoczął się 29 lipca i trwał do 2 sierpnia. Wśród zespołów występujących na głównej scenie na stadionie i tzw. małej scenie $\mathrm{w}$ amfiteatrze znaleźli się reprezentanci większości gatunków i podgatunków rocka, a zespoły heavymetalowe bynajmniej nie były dominujące. I choć wśród wykonawców tego gatunku muzyki gwiazdą festiwalu miał być, w zamierzeniu organizatorów, obchodzący wówczas pięciolecie istnienia zespół TSA, to jednak jego występ nie spotkał się z uznaniem fanów gatunku,

\footnotetext{
${ }^{42}$ P. Szarszewski, op. cit., s. 39

43 AIPN, 001708/4047, G. Banaszewski, Działalność młodzieżowych..., s. 27.

${ }^{44}$ M. Zawadzki, Komunikacja werbalna i niewerbalna subkultury satanistów i metalowców. Podobieństwa i różnice obu grup, w: Ezoteryzm, okultyzm..., s. 183.

45 Obecnie Wieża Gocławska w Szczecinie.

${ }^{46}$ A. Mikołejko, op. cit., s. 125-126.
} 
którzy po występach na jarocińskiej scenie oczekiwali znacznie bardziej nowoczesnego, ofensywnego metalu, niż ten, który prezentowali muzycy TSA. Znacznie lepiej został przyjęty występ zespołu Kat, który 31 lipca w zasadzie powtórzył spektakl zaprezentowany cztery miesiące wcześniej podczas Metalmanii. Jednak to nie Kat stał się tym razem przedmiotem zainteresowania mediów, a wykonująca dynamiczny thrash metal wrocławska grupa Test Fobii Kreon, której wokalista Zbigniew Zaranek podczas koncertu złamał, a następnie podpalił krzyż. Zapewne, gdyby nie „czarna msza”, do której doszło w Jarocinie tej samej nocy, występ tego zespołu i zachowanie jego lidera umknęłyby czyjejkolwiek uwadze, nie licząc publiczności. Tymczasem Zaranek stał się czarnym bohaterem artykułów prasowych, a całe wydarzenie znalazło swój epilog na sali sądowej. Podczas procesu, wytoczonego z powództwa Episkopatu Polski, zaprzeczał on, jakoby jego akt miał podłoże satanistyczne i był elementem jakiegokolwiek rytuału, i twierdził, że kierowany wolnością wypowiedzi artystycznej w ten sposób zaprotestował tylko przeciwko niektórym praktykom Kościoła, z którym się nie zgadzał ${ }^{47}$. Mimo że został uniewinniony, a on i pozostali członkowie zespołu publicznie odżegnywali się od związków z satanizmem, wrzawa medialna zrobiła swoje i nawet w opracowaniach naukowych funkcjonował jako jeden $\mathrm{z}$ „głównych kapłanów i ideologów satanizmu w Polsce" 48 .

Przyczyną medialnej wrzawy i zainteresowania, z jakimi w 1986 r. spotkały się jarocińskie występy Kata i Testu Fobii Kreona był fakt, że właśnie podczas trwania Festiwal Muzyków Rockowych w Jarocinie, w nocy 1 na 2 sierpnia, odprawiona została „czarna msza”. Za jej inicjatorów uważa się dwudziestojednoletniego Wojciecha J. mieszkańca Polichna oraz siedemnastoletniego Tomasza J. ze Szczecina. Obydwaj byli fanami muzyki heavymetalowej. Tomasz J., który już wcześniej brał udział w podobnej „mszy” zorganizowanej w Wieży Bismarcka w Szczecinie, postanowił, że będzie pełnić funkcję „kapłana”. Tego samego dnia ukradli stułę z konfesjonału w kościele św. Jerzego w Jarocinie. Około godziny 23 wraz grupą 20-25 osób udali się na jarociński cmentarz, ze starej kaplicy grobowej wyciągnęli trumnę i przenieśli ją do pobliskiego lasu. Złapano kota oraz psa, jednak ten pierwszy na swoje szczęście zdołał uciec oprawcom. Z cmentarza zabrano również znicze, które następnie płonące ustawiono na trumnie. Ceremonii, rozpoczętej kilkanaście minut przed północą, przewodził Tomasz J. jako „kapłan” i rozebrany do pasa Wojciech J. Według relacji świadków, kiedy Tomasz J., wymawiał rzekomo magiczne formuły obrzędu, Wojciech J. przytrzymywał położonego na brzegu trumny żywego psa, skrępowanego stułą. W kulminacyjnym momencie „mszy”, około północy, zabił nożem zwierzę i rozpruwszy

\footnotetext{
47 P. Szarszewski, op. cit., s. 39.

48 A. Mikołejko, op. cit., s. 125-126; J. Szubrycht, Histeria satanizmu, „Polityka” 2015, nr 44, s. 88 .
} 
jamę brzuszną wyjął zeń wnętrzności i serce, które podał „kapłanowi”, a ten rzucił nim o trumnę $e^{49}$.

Jeszcze tak samej nocy o tym, co zaszło na jarocińskim cmentarzu, zrobiło się głośno wśród uczestników festiwalu. Równie szybko o incydencie dowiedzieli się funkcjonariusze MO, którzy natychmiast podjęli działania operacyjne. Wylegitymowano oraz zatrzymano do wyjaśnienia około 150 osób, w większości niepełnoletnich. Byli wśród nich również uczestnicy „czarnej mszy”. Ich zeznania pozwoliły zrekonstruować jej przebieg i umożliwiły zatrzymanie sprawców, przeciwko którym prokurator skierował akt oskarżenia do sądu rejonowego w Jarocinie. Przyznali się do popełnionych czynów z art. $197 \$ 1$ kodeksu karnego, tj. znieważenia zwłok, prochów ludzkich i miejsca spoczynku zmarłego oraz art. 5 i art. 2 rozporządzenia Prezydenta Rzeczypospolitej z 22 marca 1928 r. o ochronie zwierząt. Przed sądem szczegółowo wyjaśnili okoliczności i motywy swojego postępowania, przy czym podkreślali, iż popełniając owe czyny, kierowali się powinnościami wynikającymi z przynależności do sekty Czcicieli Szatana. Dopytywani o szczegóły, nie potrafili jednak dokładnie określić, na czym polegała jej ideologia. Wojciech J. stwierdził, że nie wie, czy formuła obrzędu i modły wznoszone przez Tomasza J. pochodziły z Biblii Szatana. Mimo że od trzech lat uważał się za satanistę, to nie czytał tej książki ani nawet nie miał jej w rękach. Wyrokiem Sądu Rejonowego w Jarocinie Wojciech J. został skazany na 1 rok i 6 miesięcy pozbawienia wolności oraz 100 tys. złotych grzywny na rzecz Towarzystwa Opieki nad Zwierzętami w Polsce, natomiast Tomasz J. na karę 1 roku pozbawienia wolności ${ }^{50}$.

Prasa, korzystając z kanikuły, szybko podchwyciła temat i satanizm oraz „czarna msza” jeszcze w sierpniu 1986 r. zagościły na stronach większości gazet. Wydarzenia z Jarocina zaskoczyły i zbulwersowały opinię publiczną, tym bardziej że w prasie dominował przejaskrawiony, często bardzo emocjonalny przekaz ${ }^{51}$. Piotr Szarszewski uważa, że „czarna msza jarocińska stanowi pewną cezurę czasową określa moment zaistnienia satanizmu w mediach, a za ich pośrednictwem także w świadomości społecznej”52.

49 AIPN, 001708/4047, G. Banaszewski, Działalność młodzieżowych..., s. 30; ibidem, 001708/2919, J. Krobski, Nieformalne ruchy..., s. 14-15; P. Szarszewski, op. cit., s. 39-40; J.W. Wójcik, Od hipisów do satanistów, Kraków 1992, s. 152-154.

50 AIPN, 001708/4047, G. Banaszewski, Działalność młodzieżowych..., s. 45-47; ibidem, 001708/ 2919, J. Krobski, Nieformalne ruchy..., s. 15. Tomasz J. po odbyciu kary kilkakrotnie jeszcze przyjeżdżał na jarociński festiwal, zawsze chętnie udzielając prasie wywiadów na temat zajścia oraz motywów, które nim kierowały. Podkreślał w nich, że satanizm pozwolił mu pozbyć się kompleksów, wyrok zaś uczynił z niego jedynego „męczennika” polskiego satanizmu, P. Szarszewski, op. cit., s. 40.

51 B. Hoffmann, op. cit., s. 1-2.

52 P. Szarszewski, op. cit., s. 41. 
Artykuły poświęcone satanizmowi, które po wydarzeniach latem 1986 r. w Jarocinie trafiły na łamy prasy, zasługują na osobną, pogłębioną analizę ${ }^{53} . \mathrm{Na}$ informacje dotyczące tej problematyki można się natknąć zarówno w gazetach codziennych (m.in. „Dziennik Bałtycki”, „Gazeta Krakowska”, „Gazeta Poznańska”, „Sztandar Młodych”, „Trybuna Robotnicza”, „Życie Warszawy”), jak i w opiniotwórczych tygodnikach (m.in. „Polityka”, „Prawo i Życie”, „Tygodnik Powszechny"), w tym również w czasopismach skierowanych do młodzieży (m.in. „Na Przełaj”, „Razem”). Teksty o satanizmie pojawiały się również na łamach tytułów o znacznie mniejszym nakładzie i zasięgu, ale mających stałe grono czytelników, w czym osoby związane z resortem spraw wewnętrznych widziały jedną z pierwszorzędnych przyczyn popularyzacji tego zjawiska ${ }^{54}$. Przykładowo po tym, jak w „Dzienniku Bałtyckim” w grudniu 1986 r. ukazały się artykuły poświęcone działalności grup satanistycznych, funkcjonariusze SB na terenie Trójmiasta odnotowali, iż niemal natychmiast pojawiły się sensacyjne i wyolbrzymione pogłoski o istnieniu licznych grup satanistycznych i opisujące rzekome akty przemocy, których ich członkowie mieli dopuścić się na obszarze województwa gdańskiego ${ }^{55}$.

Prasa była bez wątpienia podstawowym źródłem informującym o zjawisku satanizmu, w wielu przypadkach inspirującym młodych ludzi lub dopełniającym ich dotychczasową, często fragmentaryczną wiedzę na ten temat uzyskaną od rówieśników. Osoby zatrzymywane przez milicję i przesłuchiwane pod zarzutem przestępstw i wykroczeń, w których pojawiał się kontekst satanistyczny, często przyznawały, że artykuły w gazetach były głównym, a niejednokrotnie jedynym źródłem wiedzy o satanizmie.

Istotną rolę odegrała również telewizja, zwłaszcza film pt. Oto Ameryka, który w dwóch częściach wyemitowano późnym wieczorem w kolejne piątki 28 listopada i 5 grudnia 1986 r. ${ }^{56}$ Obraz z 1977 r. w reżyserii Romana Vanderbesa był dokumentem utrzymanym w konwencji tzw. filmu szokującego (Shockumentary movies), w którym zaprezentowano nietypowe, często skandaliczne upodobania mieszkańców USA, od karnawału w Nowym Orleanie i udawanych zapasów, przez

53 Taką próbę podjął na początku lat dziewięćdziesiątych XX w. Jerzy Wojciech Wójcik, jednak nie uwzględnił wszystkich tekstów i publikacji, które ukazały się na ten temat przed 1990 r., a w większości przypadków ograniczył się do wymienienia tytułu i źródła publikacji, analizując jedynie zawartość niektórych z nich, zob. J.W. Wójcik, op. cit., s. 183-187.

54 AIPN, 0236/420, Informacja w sprawie młodzieżowego ruchu „satanistów” i wynikających z niego zagrożeń, Lublin 5 IX 1987, k. 57-58; AIPN Gd, 565/138, Informacja o dotychczasowych ustaleniach i wykonanych czynnościach dot. działalności nieformalnej grupy młodzieżowej „Czcicieli Szatana” tzw. Satanistów, Gdańsk 16 XII 1986, k. 167.

55 AIPN, 0236/420, Pismo zastępcy naczelnika Wydziału IV WUSW w Gdańsku do naczelnika Wydziału VI Departamentu IV MSW w Warszawie dot. działalności tzw. satanistów, Gdańsk 28 VIII 1987, k. 65.

56 Telewizja, „Trybuna Robotnicza” 28 XI 1986, nr 278, s. 7; Telewizja, „Trybuna Robotnicza” 5 XII 1986 , nr 284, s. 7. 
dewiacje seksualne, aż po Kościół Szatana i czarną mszę. Projekcja filmu, wcześniej wielokrotnie zapowiadanego, miała na celu ukazanie moralnego i obyczajowego upadku Amerykanów i wpisywała się w propagandową krytykę ustroju kapitalistycznego, a zwłaszcza stosunków społecznych panujących w USA, uprawianą przez reżimowe media. Film spotkał się z zainteresowaniem telewidzów, wśród których, pomimo później pory emisji, znalazło się sporo młodzieży. Co więcej, zarejestrowany na domowych magnetowidach, krążył w kopiach po kraju. Dla niektórych był jednym z głównych źródeł wiedzy o praktykowanym we wspólnocie satanistycznej za oceanem obrzędzie „czarnej mszy”. Sceny z filmu trafiły na podatny grunt. Tym bardziej że jego emisja przypadła na okres gwałtownego wzrostu popularności zespołów heavymetalowych, zarówno zagranicznych, jak i rodzimych, mających w swoim repertuarze satanistyczne teksty. Do inspiracji filmem Oto Ameryka przyznawali się uczestnicy rzekomo satanistycznych obrzędów odprawionych w kaplicy cmentarnej w Wałbrzychu ${ }^{57}$.

„W telewizji widziałem, jak chłopak wyrwał krzyże, obciąłem podobnie. Warto pokazać, że nasze miasteczko nie jest gorsze. To było coś nowego, taki szpan, nie wiem w jakim celu" - zeznał w trakcie śledztwa szesnastoletni uczeń II klasy Zespołu Szkół Mechanicznych w Człuchowie, który na tamtejszym cmentarzu jesienią 1986 r. zniszczył pięćdziesiąt krzyży. Z kolei szesnastoletni uczeń III klasy Zespołu Szkół Zawodowych we Wrześni stwierdził, że satanizmem zainteresował się jesienią 1986 r., po przeczytaniu artykułu w gazecie. Chcąc zaakcentować obecność satanistów w swoim mieście, namówił trzech kolegów i wspólnie, we wrześniu i październiku 1987 r., na wrzesińskim cmentarzu niszczyli nagrobki i wyrywali krzyże, które następnie ustawiali odwrotnie ${ }^{58}$.

Wydarzenia, do których doszło latem 1986 r. w Jarocinie, a następnie dewastacje cmentarzy w Człuchowie i Puszczykowie, które miały miejsce jesienią tego samego roku, zostały nie tylko rozpropagowane przez środki masowej informacji, ale dodatkowo spotęgowane przez plotki. Funkcjonariusze SB w Lublinie twierdzili, że pierwsze informacje o satanistach w tym mieście pojawiły właśnie po festiwalu jarocińskim $^{59}$. Druga połowa 1986 r. to w materiałach MO i SB dosłownie wysp informacji o grupach lub pojedynczych osobach podających się za satanistów.

Jesienią 1986 r. wśród mieszkańców Wąsosza na Dolnym Śląsku (wówczas woj. leszczyńskie) zaczęła krążyć plotka, jakoby trójka młodych ludzi gromadziła się na tamtejszym cmentarzu i „odprawiała modły na grobach przy użyciu odwróconego krzyża oraz serca zabitego zwierzęcia"60. Sprawą zainteresowały

\footnotetext{
57 J. Szubrycht, op. cit., s. 88; AIPN, 001708/4047, G. Banaszewski, Działalność młodzieżowych..., s. $47-48,51-53$.

58 AIPN, 001708/4047, G. Banaszewski, Działalność młodzieżowych..., s. 53-54.

59 AIPN, 0236/420, Informacja w sprawie młodzieżowego ruchu „satanistów” i wynikających z niego zagrożeń, Lublin 5 IX 1987, k. 52.

${ }^{60}$ AIPN Po, 0120/261, Notatka urzędowa, Wąsosz 7 XI 1986, mf, k. 14.
} 
się milicja i SB. Dość szybko ustalono, że w miasteczku faktycznie zawiązała latem 1986 r. nieformalna grupa złożona z chłopców w wieku 16-18 lat, którzy spotykali się w miejscach ustronnych, m.in. nad rzeką i w okolicach cmentarza, gdzie, jak stwierdzono, „dokonują wymyślonych przez siebie obrzędów”. Pod koniec października 1986 r. zabili psa nad rzeką Orlą. Gdy kilka dni później próbowali dokonać podobnego czynu na cmentarzu w Wąsoczu, zostali przegonieni przez miejscowych mieszkańców ${ }^{61} .1$ listopada 1986 r. na cmentarzu komunalnym w Wałczu nieustaleni sprawcy po uśmierceniu psa powiesili go na krzyżu nagrobkowym ${ }^{62}$. Zabójstwa psów wskazywały na inspirację wydarzeniami w Jarocinie. Nie zawsze jednak decydowano się na tak drastyczną formę „ofiary”. Ośmiu chłopców ze Strzelec Opolskich, w wieku od 14 do 16 lat, którzy twierdzili, że są satanistami i spotykali się w poniemieckim bunkrze przeciwlotniczym oraz lasku za miastem, gdzie odprawiali rzekomo satanistyczne obrzędy, spalili zdechłego kota ${ }^{63}$. Przypadki męczenia zwierząt spotkały się z potępieniem ze strony większości członków zespołów kojarzonych z satanizmem. Roman Kostrzewski z katowickiego Kata w wypowiedzi dla prasy stwierdził, że „to mogły zrobić tylko osoby nieodpowiedzialne. Prawdziwy satanista nigdy nie odważyłby się zamordować zwierzęcia, bo szanuje każdy rodzaj istot żywych"64.

Częściej niż w poprzednich latach dochodziło do dewastacji cmentarzy. Sprawcami byli najczęściej upojeni alkoholem i naładowani testosteronem młodzieńcy. Większość z nich, jak twierdziła milicja, nie miała związków z żadnymi grupami subkulturowymi ani nie uważała się za czcicieli szatana. I tak pierwszym przestępstwem przypisywanym $\mathrm{w}$ mediach satanistom miała być dewastacja cmentarza w Mińsku Mazowieckim w październiku 1983 r., jednak zdaniem pracowników aparatu ścigania zniszczenia nagrobków nie były dziełem satanistów ${ }^{65}$. Zdarzały się jednak czyny świadczące o „satanistycznym podłożu”. Na przykład w listopadzie 1986 na cmentarzu w Złocieńcu dwóch siedemnastolatków przewracało krzyże oraz odrywało z nich wizerunki Chrystusa. Jeden z nich zeznał w śledztwie, że „chcieliśmy te figurki nosić na szyi, lecz odwrotnie do góry nogami, czyli na znak Szatana"66. Miesiąc później trzech mężczyzn w wieku 16-18 lat uszkodziło około 40 grobów i poprzewracało krzyże na dwóch nieczynnych cmentarzach w Pile. Część z krzyży wbito w ziemię odwrotnie ${ }^{67}$. W tym samum miesiącu dwaj chłopcy,

${ }^{61}$ AIPN Po, 0120/261, Notatka służbowa, Wąsosz 19 XI 1986, mf, k. 18.

62 AIPN, 0236/420, Pismo naczelnika Wydziału IV WUSW w Pile do naczelnika Wydziału VI Departamentu IV MSW w Warszawie dot. działalności grup satanistów, Piła 8 IX 1987, k. 60.

${ }^{63}$ J.W. Wójcik, op. cit., s. 167.

${ }^{64}$ Cyt. za ibidem, s. 148.

65 AIPN, 001708/4047, G. Banaszewski, Działalność młodzieżowych..., s. 30-31.

${ }^{66}$ Ibidem, s. 150.

${ }^{67}$ AIPN, 0236/420, Pismo naczelnika Wydziału IV WUSW w Pile do naczelnika Wydziału VI Departamentu IV MSW w Warszawie dot. działalności grup satanistów, Piła 8 IX 1987, k. 60. 
w wieku 14 i 15 lat dokonali zniszczeń 86 grobów na cmentarzu w Chełmie. Zatrzymani twierdzili, że należą do „wyznawców Szatana” i „ruchu satanistów”68. Podobny charakter miała dewastacja cmentarza komunalnego w Wałczu latem 1987 r., gdzie młodociani sprawcy również poprzewracali krzyże nagrobne, część $\mathrm{z}$ nich odwrotnie wbijając w ziemię ${ }^{69}$. Takich samych czynów dopuścili się członkowie wspomnianej już wcześniej nieformalnej grupy ze Strzelec Opolskich ${ }^{70}$. Sprawcy podobnych aktów wandalizmu dokonanych w tym samym czasie na cmentarzu w Rybniku, zatrzymani przez milicję twierdzili, że byli wyznawcami kultu Szatana ${ }^{71}$. W Opolu Lubelskim we wrześniu 1988 r. nieletni sprawcy przewracali płyty nagrobkowe i krzyże, które również ustawiali odwrotnie. Odnaleźli także miejsce składowania przez grabarzy ludzkich szczątków z likwidowanych grobowców, skąd zabrali do domu czaszki. Próbowali ukraść sporych rozmiarów krzyż nagrobkowy, jednak okazał się zbyt ciężki i porzucili go niedaleko cmentarza. „Krzyż ten zabraliśmy, żeby wykorzystać go do odprawienia mszy satanistycznej, gdyż czuję się satanistą", zeznał przed sądem jeden ze sprawców ${ }^{72}$.

Ponieważ o tych i podobnych wydarzenia informowały lokalne media, a i bez tego były one "pocztą pantoflową" przekazywane dalej, satanizm w ciągu paru miesięcy stał się tematem, który rozpalał wyobraźnię. I jeśli jeszcze do niedawna nie zdawano sobie $w$ ogóle sprawy $z$ jego istnienia, teraz tworzono jego przejaskrawiony i zmitologizowany obraz. Powszechne było mniemanie, że sataniści uprawiają orgie seksualne, porywają i gwałcą dziewczęta, a nawet mordują dzieci (przeważnie małe dziewczynki), a następnie odprawiają nad ich zwłokami swoje obrządki. Tego rodzaju plotki co jakiś czas elektryzowały opinię publiczną, powodując najczęściej niepokój wśród rodziców. Wiosną 1987 r. przed trzecią pielgrzymką Jana Pawła II do Polski po kraju krążyła plotka, że sataniści będą składać ofiary z dzieci dla „uczczenia” pobytu. Twierdzono, że zamordowanych miało zostać $150 \mathrm{dzieci}^{73}$. Inną wersją tej samej plotki były pogłoski o rzekomym satanistycznym spisku, którego uczestnicy zamierzają zamordować 99 dzieci, a na koniec samego papieża, który miał być setną, najważniejszą ofiarą ${ }^{74}$. W tym samym czasie podwarszawskie Piaseczno paraliżowała plotka o rzekomo rytualnym, niezwykle brutalnym mordzie popełnionym na osiemdziesięciojednoletniej

${ }^{68}$ J.W. Wójcik, op. cit., s. 150.

69 AIPN, 0236/420, Pismo naczelnika Wydziału IV WUSW w Pile do naczelnika Wydziału VI Departamentu IV MSW w Warszawie dot. działalności grup satanistów, Piła 8 IX 1987, k. 60-61.

${ }^{70}$ J.W. Wójcik, op. cit., s. 167.

71 AIPN, 0236/420, Pismo naczelnika Wydziału VI dep. IV MSW do naczelnika Wydziału IV WUSW w Katowicach dot. działalności grupy „Sataniści”, Warszawa 3 IX 1987, k. 59.

72 J.W. Wójcik, op. cit., s. 167-168.

73 Ibidem, s. 157.

${ }^{74}$ AIPN, 0236/420, Informacja w sprawie młodzieżowego ruchu „satanistów” i wynikających z niego zagrożeń, Lublin 5 IX 1987, k. 53. 
staruszce. Kobietę faktycznie zamordowano, jednak, jak się okazało, sprawcami nie byli sataniści ${ }^{75}$. Psychoza strachu opanowała mieszkańców Chojnic, kiedy miasto obiegła wiadomości o samobójczej śmierci trzynastoletniego chłopca. Również i ta śmierć, zdaniem autorów plotki, miała była mordem rytualnym dokonanym przez satanistów. Pomimo że milicja dementowała te informacje, rodzice na wszelki wypadek zabraniali wychodzenia swoim dzieciom z domu po $\mathrm{zmroku}^{76}$.

Wystarczyło nosić czarną kurtkę skórzaną lub troszkę dłuższe włosy, aby być wziętym za satanistę. W szkole $\mathrm{w}$ Jastkowie był przypadek wskazania przez dzieci funkcjonariuszowi MO satanisty, który rzekomo dostał się do szkoły w niewiadomym zamiarze. Po zatrzymaniu i wylegitymowaniu mężczyzny ubranego w czarną, skórzaną kurtkę okazało się, że był on mężem nauczycielki, który przyszedł odwiedzić swoją żonę 77 .

Dostrzeżenie przez dziennikarzy, jak również MO i SB nieformalnych, przeważnie kilkuosobowych grup subkultury metalowej na terenie Trójmiasta również było pokłosiem medialnej wrzawy w drugiej połowie $1986 \mathrm{r}$. Podejrzewano, że są wśród nich sataniści. Informacje o nich w lokalnej prasie stały się w pierwszej połowie 1987 r. pożywką dla licznych plotek, wśród których dominowały opisy rzekomych aktów przemocy, jakich mieli oni dopuszczać się na terenie województwa gdańskiego ${ }^{78}$.

Jak wskazuje przykład Trójmiasta, autorami plotek byli często sami członkowie grup rówieśniczych. Wśród informacji o satanistach krążących w 1987 r. wśród mieszkańców tej aglomeracji pojawiły się m.in. twierdzenia, że nowo przyjętych adeptów kultu Szatana poddawano tzw. próbie krwi, polegającej na spożywaniu krwi z ciała zwierzęcia zabitego w trakcie "czarnej mszy”. Chłopcy mieli dokonywać aktów rytualnego samookaleczenia, natomiast dziewczęta uczestniczyć w orgiach seksualnych. Jak ustalili funkcjonariusze SB, zachowania te pozostawały „raczej $w$ sferze spekulacji niż praktyki i informacje takie rozpowszechniane były (z zamiarem imponowania) przez samych satanistów bądź przez osoby psychicznie niezrównoważone" ${ }^{39}$. Nie znalazły również potwierdzenia

75 J.W. Wójcik, op. cit., s. 158; A. Mikołejko, op. cit., s. 125-126.

76 AIPN, 0236/420, Informacja dot. działalności satanistów na terenie woj. bydgoskiego, Bydgoszcz VIII 1987, k. 63-64.

77 AIPN, 0236/420, Informacja w sprawie młodzieżowego ruchu „satanistów” i wynikających z niego zagrożeń, Lublin 5 IX 1987, k. 53.

78 AIPN Gd, 565/138, Informacja o dotychczasowych ustaleniach i wykonanych czynnościach dot. działalności nieformalnej grupy młodzieżowej „Czcicieli Szatana” tzw. Satanistów, Gdańsk 16 XII 1986, k. 163; AIPN, 0236/420, Pismo zastępcy naczelnika Wydziału IV WUSW w Gdańsku do naczelnika Wydziału VI Departamentu IV MSW w Warszawie dot. działalności tzw. satanistów, Gdańsk 28 VIII 1987, k. 65-66.

${ }^{79}$ AIPN, 0236/420, Pismo zastępcy naczelnika Wydziału IV WUSW w Gdańsku do naczelnika Wydziału VI Departamentu IV MSW w Warszawie dot. działalności tzw. satanistów, Gdańsk 28 VIII 1987, k. 66. 
inne, często makabryczne plotki o rzekomych ekshumacjach ludzkich szczątków z grobowców ${ }^{80}$.

Pomimo że od „czarnej mszy” w Jarocinie minął rok, medialna wrzawa wokół satanizmu nie ustawała. Spora część dziennikarzy, którzy na początku sierpnia 1987 r. ponownie przybyli do Jarocina, liczyła na uzyskanie sensacyjnego materiału, najlepiej wywiadu z którymś z satanistów lub osobą biorącą udział w satanistycznych obrzędach, a przynajmniej jakichś informacji bulwersujących opinię publiczną ${ }^{81}$. Stąd zapewne w relacjach prasowych skupiano się przede wszystkim na opisach kontrowersyjnych zachowań wykonawców i uczestników festiwalu, a tylko znikoma część relacji prasowych dotyczyła muzyki i prezentowanych zespołów. Z kolei wśród mieszkańców Jarocina krążyła plotka, jakoby sataniści zamierzali zamordować pięć dziewczynek, w ten sposób chcąc pomościć wyroki sądowe, które otrzymali w ubiegłym roku ich współwyznawcy. Dlatego też wiele matek zabroniło swoim dzieciom wychodzić $\mathrm{z}$ domu w trakcie trwania festiwalu ${ }^{82}$.

Przed wizytą Jana Pawła II w Lublinie zaplanowaną na 9 czerwca 1987 r. działania przeciwko satanistom prowadziły wspólnie $\mathrm{MO}$ i SB, w związku z informacją o mającym się z tej okazji odbyć 6 czerwca zlocie satanistów w Parku Saskim w Lublinie oraz wspomnianymi wcześniej plotkami o rzekomych planach zamachu na papieża ${ }^{83}$. Działania milicji rozpoczęto w kwietniu 1987 r. i miały one na celu przede wszystkim rozpoznanie i infiltrację środowiska satanistów na terenie miasta i województwa lubelskiego. Osoby, które podejrzewano, iż są liderami grup satanistycznych, zatrzymano do wyjaśnienia, wykonano im fotografie sygnalityczne oraz pobrano odciski palców. Natomiast wszystkie osoby posądzane o związki satanizmem zarejestrowano w kartotece Sekcji Ewidencji i Poszukiwań Wydziału Kryminalnego Komendy Wojewódzkiej w Lublinie. Ponadto poszczególnym jednostkom MO wydano polecenie prowadzenia na bieżąco rozpoznania tego środowiska $w$ ramach tzw. teczek zagadnieniowych ${ }^{84}$. Podobne działania prowadził na terenie Warszawy Wydział Kryminalny Stołecznego Urzędu Spraw Wewnętrznych w ramach sprawy o kryptonimie „Sataniści” ${ }^{\text {. }}$.

Według ustaleń Jerzego Wojciecha Wójcika w latach 1986-1990 przestępstwa i wykroczenia, których sprawcami były osoby uważające się za satanistów lub tak zakwalifikowane przez milicję, dokonane zostały w 35 województwach.

${ }^{80}$ Ibidem, k. 67.

81 AIPN Ld, 0044/15, t. 4, Festiwal Rockowy Jarocin'87 - materiał opracowany na bazie rozpoznania operacyjnego, Kalisz 1987, k. 5.

82 AIPN Ld, 663/3, Szyfrogram WUSW w Kaliszu dot. pierwszego dnia trwania festiwalu w Jarocinie, Kalisz 7 VIII 1987, k. 24; ibidem, Meldunek o stanie bezpieczeństwa i porządku publicznego w trakcie Festiwalu Muzyków Rockowych Jarocin'87, Jarocin 7 VIII 1987, k. 28.

83 AIPN, 0236/420, Informacja w sprawie młodzieżowego ruchu „satanistów” i wynikających z niego zagrożeń, Lublin 5 IX 1987, k. 55.

84 Ibidem, k. 59.

${ }^{85}$ AIPN, 001708/4047, G. Banaszewski, Działalność młodzieżowych..., s. 32-33. 
W większości przypadków były to dewastacje cmentarzy i miejsc kultu, znęcanie się nad zwierzętami oraz kradzieże przedmiotów kultu religijnego z kościołów, kaplic i cmentarzy. Znieważenia miejsca spoczynku zmarłych odnotowano w 27 województwach, $\mathrm{z}$ czego najwięcej w województwie stołecznym warszawskim oraz w katowickim, szczecińskim, łódzkim, poznańskim, pilskim, opolskim i włocławskim. Przestępczość ta miała tendencję rosnącą. O ile w 1986 r. zanotowano w całym kraju pięć przypadków dewastacji cmentarzy przez grupy młodzieżowe, to w roku 1990 stwierdzono ich aż 38. Jednak, o czym była już wcześnie mowa, na pewno nie wszystkie $\mathrm{z}$ tych aktów wandalizmu można bezsprzecznie uznać za dzieło satanistów. Ponadto należy wziąć pod uwagę fakt, na co zwrócił również uwagę Jerzy Wojciech Wójcik, że milicja nie prowadziła odrębnej kartoteki dla „przestępstw satanistycznych”, stąd szacunki te na pewno wymagają dalszych badań i doprecyzowania ${ }^{86}$.

Druga połowa lat osiemdziesiątych była okresem żywiołowego rozwoju subkultur młodzieżowych w Polsce, w tym również satanizmu młodzieżowego. Do Polski docierają wówczas pierwsze, angielskojęzyczne wydania biblii satanistycznej, które zaczynają krążyć w nieprofesjonalnych tłumaczeniach, przepisywanych lub powielanych fragmentach. Korzystają $\mathrm{z}$ nich również dziennikarze, o czym świadczy m.in. streszczenie ideologii zawartej w biblii satanistycznej, które ukazało się w reportażu opublikowanym w lipcu 1987 r. na łamach bydgoskiego tygodnika

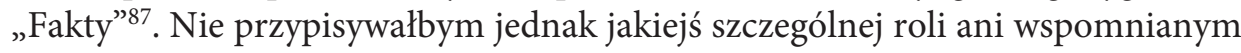
odpisom tłumaczeń, ani tego rodzaju publikacjom prasowym. Barbara Hoffmann, która pod koniec lat osiemdziesiątych przeprowadziła wywiady z osobami twierdzącymi, że są satanistami, stwierdziła, iż niewielu z badanych czytało fragmenty tłumaczeń Biblii Szatana, większość tylko o niej słyszała, a zdarzali się i tacy, którzy o takiej książce i jej autorze dowiedzieli się dopiero od badaczki w trakcie przeprowadzania wywiadu ${ }^{88}$. Trudno zatem zgodzić się z twierdzeniem Anny Mikołejko, że to „Biblia LaVeya [stanowiła] główne - choć nie zawsze dostępne bezpośrednio - źródło polskiego satanizmu młodzieżowego"89.

Większość osób zatrzymanych przez MO i SB wiosną 1987 r. w Lublinie, w ramach przywołanej już wcześniej akcji zmierzającej do inwigilacji i rozbicia środowisk satanistycznych, twierdziła, że satanistami zostali niejako „przypadkiem”. Będąc fanami metalu, jeździli na koncerty i zloty, gdzie spotykali osoby o podobnych zainteresowaniach i fascynacjach i to one wprowadzały ich w świat satanistycznych wierzeń. Większość nie zastanawiała się jednak głębiej nad satanizmem, przyswajając wyłącznie zewnętrzne atrybuty (strój, naszywki). Tylko nieliczni twierdzili, że był to z ich strony przemyślany wybór, gdyż zawiedli się

\footnotetext{
${ }^{86}$ J.W. Wójcik, op. cit., s. 155-157.

87 R.T. Prinke, Królestwo szatana, „Fakty” 4 VII 1987, nr 27.

88 B. Hoffmann, op. cit., s. 54.

${ }^{89}$ A. Mikołejko, op. cit., s. 123.
} 
na dotychczasowych wzorcach oraz religii chrześcijańskiej ${ }^{90}$. Podobną opinię wystawili młodocianym sprawcom przestępstw i wykroczeń o satanistycznym podtekście funkcjonariusze SB z Piły, stwierdzając, że w motywach, które stały za popełnionymi czynami brak było głębszej motywacji wynikającej z jakichś określonych przekonań. Wiadomości dotyczące ruchu satanistycznego były wśród zatrzymanych znikome i pochodziły przede wszystkim ze środków masowego przekazu i z opowiadań kolegów, a zainteresowanie satanizmem było wynikiem mody i presji środowiskowej ${ }^{91}$.

O tym, jak powierzchowne było ideologiczne zaplecze sprawców czynów kwalifikowanych jako satanistyczne, świadczy wydarzenie, do którego doszło w maju 1989 r. w Polkowicach, gdzie zatrzymano dwóch mężczyzn w wieku 17 i 20 lat. Włamali się oni do jednej z kaplic grobowych z przełomu XIX i XX w. i po otwarciu trumny wynieśli stamtąd szczątki kobiety, które odnaleziono kilka metrów dalej z oderwaną czaszką. Przesłuchiwani zaprzeczali, by byli satanistami, twierdząc, że należą do „subkultury metalowców" 92 .

„Każdy satanista to heavy metalowiec, choć nie każdy heavy metalowiec to satanista", cytowała jednego ze swoich rozmówców autorka reportażu opublikowanego w lipcu 1987 r. w „Panoramie Lubelskiej”93. Również niektórzy funkcjonariusze MO i SB dość szybko zorientowali się, że większość fanów heavy metalu, choć obnosiła się z satanistyczną symboliką, nie miała z satanizmem wiele wspólnego. Dla większości milicjantów, wychowawców, pedagogów i rodziców różnice te były jednak niezauważalne ${ }^{94}$. Koresponduje z tym twierdzenie Marcina Zawadzkiego, który uważa, że pod wieloma względami subkultura metalowców jest odrębna od kultury satanistów, jednak dla wielu postronnych obserwatorów stanowią one jednolitą wewnętrzną całość, gdyż znajomość tych grup ogranicza się jedynie do rozpoznania zewnętrznych atrybutów tych społeczności ${ }^{95}$.

Funkcjonariusze SB, poza sporadycznymi przypadkami związanymi z inwigilacją uczestników festiwalu w Jarocinie i pojedynczymi sprawami operacyjnego rozpracowania, nie dostrzegali w subkulturze metalowej, a tym bardziej w pojawiającej się na jej obrzeżach ideologii satanistycznej zagrożenia dla państwa i ustroju. Grupy określające się mianem satanistycznych zasadniczo nie były przedmiotem zainteresowania pracowników Departamentu IV MSW i podległych im wydziałów

90 AIPN, 0236/420, Informacja w sprawie młodzieżowego ruchu „satanistów” i wynikających z niego zagrożeń, Lublin 5 IX 1987, k. 55.

91 AIPN, 0236/420, Pismo naczelnika Wydziału IV WUSW w Pile do naczelnika Wydziału VI Departamentu IV MSW w Warszawie dot. działalności grup satanistów, Piła 8 IX 1987, k. 61.

92 AIPN, 0236/420, Pismo naczelnika Wydziału IV WUSW w Legnicy do naczelnika Wydziału IV Dep. IV MSW w Warszawie dot. zbeszczeszczania zwłok na cmentarzu parafialnym w Polkowicach, Legnica 24 V 1989, k. 31-33.

93 A. Chwałczyk, Kawaleria szatana, „Panorama Lubelska” 4 VII 1987.

${ }^{94}$ AIPN, 001708/2919, J. Krobski, Nieformalne ruchy..., s. 32.

95 M. Zawadzki, op. cit., s. 182. 
i struktur terenowych. Również pracownicy Urzędu ds. Wyznań nie traktowali zjawiska satanizmu jako tematu godnego zainteresowania i analiz. Minister, kierownik Urzędu do spraw Wyznań, Władysław Loranc, podczas spotkania z członkami krakowskiego Stowarzyszenia „Kuźnica” w kwietniu 1989 r. zapytany o problem satanizmu odpowiedział, że „kwestia satanistów jest $\mathrm{z}$ naszego punktu widzenia nieistotna. Bardziej powinni się nią zainteresować psycholodzy"96.

Nie wydaje się, by odpowiadały rzeczywistości typologie polskiego satanizmu, które powstały w latach osiemdziesiątych i do dziś bywają powielane w opracowaniach dotyczących tej tematyki. Próba stworzenia jednego, powszechnie obowiązującego podziału grup satanistycznych działających w Polsce wydaje się nierozwiązywalnym problemem wciąż frapującym badaczy ${ }^{97}$. Pierwszą próbę podjęli w 1987 r. funkcjonariusze Rejonowego Urzędu Spraw Wewnętrznych w Kaliszu, którzy w oparciu o materiały zebrane w trakcie rozpracowania uczestników Festiwalu Muzyków Rockowych w Jarocinie dokonali podziału na satanistów, szatanistów i lucyferian. Typologia ta, będąca w dużej mierze wytworem fantazji uczestników festiwalu przesłuchiwanych przez milicjantów, jak i wynikiem braku rozpoznania tematu przez funkcjonariuszy przeniknęła do opracowań wewnątrzresortowych oraz do mediów i była często powielana przez publicystów i badaczy. Również podział dokonany na początku lat dziewięćdziesiątych przez Annę Mikołejko na satanistów, lucyferian oraz magiczno-okultystyczny Kościół Kirke opierał się na wątpliwych podstawach metodologicznych. Typologię, która najbardziej odpowiada rzeczywistości, zaprezentował Maciej Zawadzki, który wymienił następujące grupy satanistów: podwórkowi (dzielący się na dwie podkultury: koncertowi i subkulturowi), konfesyjni i oświeceni ${ }^{98}$. Przykłady można mnożyć, gdyż w zasadzie każdy, kto próbował w jakiś sposób zmierzyć się z tym tematem, dokonywał własnych podziałów i klasyfikacji bądź modyfikował już istniejące. Jak słusznie zauważył Piotr Szarszewski, „typologie, które być może w pełni zasługują na to, by uznać je za obowiązujące i zgodne z rzeczywistością, mają jeden podstawowy mankament. Powstały mianowicie na podstawie zbyt małej, niereprezentatywnej ilości badań. Przeprowadzenie wywiadów z zaledwie kilkunastoma satanistami, z których większość to fani muzyki heavy metal, stanowi zbyt wątłe przesłanki, by móc wysnuwać $\mathrm{z}$ tego materiału wnioski obowiązujące dla całego zjawiska" ${ }^{\prime \prime}$.

Między bajki można włożyć twierdzenia dziennikarzy, powtarzane również w niektórych opracowaniach, jakoby w 1986 r. było w Polsce około 20 tys. satanistów, posiadających swoje tajne kaplice w Krakowie, Gdańsku, Szczecinie

\footnotetext{
${ }^{96}$ G. Starzak, ... Jesteśmy egzotyczna wyspą, „Dziennik Polski” 10 IV 1989, nr 84, s. 3.

97 P. Szarszewski, op. cit., s. 74-82.

98 A. Mikołejko, op. cit., s. 124-125; M. Zawadzki, op. cit., s. 184.

99 P. Szarszewski, op. cit., s. 77.
} 
i Wrocławiu ${ }^{100}$. Najbliższe prawdy były zapewne szacunki mówiące o kilkuset osobach. Miastami, w których najczęściej MO i SB odnotowywały istnienie grup satanistycznych były Szczecin, Trójmiasto, Bydgoszcz, Torun, Wrocław, Lublin, Kraków, Katowice i Zabrze ${ }^{101}$. Jednak, jak przyznali autorzy notatki sporządzonej w 1989 r. w MSW, „w chwili obecnej nie jest możliwe precyzyjne określenie liczebności grup satanistycznych w Polsce. Związane jest to z trudnością w dotarciu do satanistów"102.

Z pewnością za sprawą muzyki w kręgu oddziaływania satanizmu znajdowały się tysiące fanów heavy metalu, jedna większość z nich nigdy nie przekroczyła granicy odrzucenia tradycyjnych wartości i identyfikacji się z satanizmem jako konfesją religijną czy światopoglądem etycznym. Co najwyżej ograniczano się do rysowania pentagramów i odwróconych krzyży w zeszytach szkolnych i na ławkach. Ponadto charakterystyczne dla polskiej kontrkultury było zjawisko tzw. sezonów, czyli osób wyłącznie okresowo bądź okazjonalnie (np. w czasie wakacji, zlotów, festiwali, koncertów) uzewnętrzniających przynależność do któregoś z jej nurtów ${ }^{103}$.

Do znajomości ideologii satanistycznej przyznawało się około 40\% osób zatrzymywanych przez MO w latach 1986-1988 w związku z działalnością satanistów. Spośród nich tylko 5\% miało za sobą doświadczenia w jakichkolwiek formach obrzędowości satanistycznej. Stąd wniosek, że pomimo sporej liczby osób, które identyfikowały się $\mathrm{z}$ satanizmem, tylko nieliczni znali założenia, a $\mathrm{w}$ zasadzie jednostki uczestniczyły w praktykach, które można by nazwać kultowymi ${ }^{104}$.

Najbardziej skrystalizowane poglądy miały osoby z dużych miast i aglomeracji miejskich, przede wszystkim z Warszawy, Szczecina, Krakowa, aglomeracji katowickiej i Trójmiasta. Złą sławą cieszyła się w całym kraju „załoga” satanistów ze Szczecina, o których mówiono, że byli „gorsi od skinów”. Wyjątkowo agresywni i zaczepni, jeździli po kraju i uczestniczyli w tzw. zadymach, które często sami prowokowali ${ }^{105}$. Agresja była jednym z zachowań charakterystycznych dla grup, których członkowie twierdzili o sobie, iż byli satanistami ${ }^{106}$. W tym sensie można satanistów zakwalifikować do subkultury, w której przemoc ma podłoże ideologiczne, co oznacza, że członkowie tych grup używają przemocy i agresji

\footnotetext{
100 J.W. Wójcik, op. cit., s. 144.

101 AIPN, 0236/420, Informacja dot. grup o charakterze satanistycznym, [1989], k. 43.

102 Ibidem.

103 A. Mikołejko, op. cit., s. 125-126.

104 AIPN, 001708/4047, G. Banaszewski, Działalność młodzieżowych..., s. 57.

105 AIPN Ld 0044/15, t. 4, Festiwal Rockowy Jarocin'87. Materiał opracowany na bazie rozpoznania operacyjnego, Kalisz 1987, k. 5.

106 Jerzy W. Wójcik podaje, na podstawie analizy akt sądowych, szczegółowe opisy przypadków przemocy i zachowań agresywnych, przede wszystkim wobec osób spoza grupy, często młodszych, J.W. Wójcik, op. cit., s. 170-177.
} 
do realizacji celów mających swe źródła w systemie wyznawanych poglądów ${ }^{107}$. $\mathrm{Z}$ przemocą i zachowaniami agresywnymi łączy się istotny aspekt ideologii satanistycznej, jakim jest kult siły rozumianej jako nietzscheańskie dążenie do mocy, panowania nad sobą i innymi. Badacze są zgodni, że kult tzw. mocnego człowieka stanowił istotny element polskiego satanizmu młodzieżowego lat osiemdziesiątych ${ }^{108}$.

Sierżant Grzegorz Banaszewski w 1990 r. dokonał analizy materiałów Biura Prewencji oraz Biura Kryminalnego KG MO, przejrzał akta spraw rozpatrywanych w latach 1986-1988 przed 13 sądami rejonowymi, a dotyczących przestępstw popełnionych w Będzinie, Brześciu Kujawskim, Chełmie, Człuchowie, Jarocinie, Kraśniku, Opolu Lubelskim, Paszczykowie k. Poznania, Strzelcach Opolskich, Wałbrzychu, Warszawie, Włocławku, Wrześni i Żarach, których dopuściło się łącznie 47 osób twierdzących, iż były satanistami lub które podejrzewano o związki $\mathrm{z}$ tą subkulturą ${ }^{109}$. W grupie tej większość stanowili mężczyźni, których było 43 (91,5\%). Liczba tylko czterech kobiet (8,5\%) świadczy, że subkultura satanistów była raczej społecznością męską. Najmłodsza osoba miała 12, najstarsza 21 lat ${ }^{110}$. Aż 38 osób (80,9\%) nie miało ukończonych 18 lat. Najwięcej, bo aż 21 (44,7\%) to byli szesnastolatkowie. Większość, bo aż 32 osoby były uczniami szkół podstawowych, dziewięć zasadniczych szkół zawodowych, jedna średniej szkoły zawodowej, jedna liceum ogólnokształcącego oraz jeden junak Ochotniczych Hufców Pracy. Cztery osoby nie uczyły się i nigdzie nie pracowały. Większość z nich borykała się z różnymi formami nieprzystosowania społecznego, a obok problemów charakterystycznych dla wieku dojrzewania dochodziły konflikty rodzinne, problemy w szkole, często nadużywanie alkoholu. Badania psychologiczne nieletnich sprawców, przeprowadzone na polecenie sądów, wykazały wiele defektów psychologicznych w rozwoju osobowości, zaburzonych postaw, zachowań i emocji. Spora część badanych miała silną potrzebę kontaktów rówieśniczych i akceptacji, przy jednocześnie małej dojrzałości społecznej i emocjonalnej. Słabe były ich związki z domem rodzinnym. Można przyjąć, że w wielu przypadkach przynależność do grup satanistycznych miała charakter ucieczki od problemów osobistych, kłopotów w szkole, braku bezpieczeństwa i uznania w rodzinie ${ }^{111}$.

\footnotetext{
107 M. Jędrzejewski, Subkultury a przemoc w perspektywie psychoedukacji, socjalizacji i samorealizacji dzieci i młodzieży, Warszawa 2001, s. 15. Pomimo to autor ten nie uwzględnia satanistów w swoich analizach.

108 P. Szarszewski, op. cit., s. 51-52; A. Mikołejko, op. cit., s. 119-120.

109 AIPN, 001708/4047, G. Banaszewski, Działalność młodzieżowych..., s. 35-36. Do podobnych wniosków doszedł Jerzy W. Wójcik, który zanalizował postępowania sądowe dotyczące 56 dorosłych i nieletnich sprawców przestępstw, których sprawy prowadzone były przez 15 sądów rejonowych, J.W. Wójcik, op. cit., s. 159-160.

110 Podobny przedział wieku (pomiędzy 13 a 20 rokiem życia) podała A. Mikołejko, op. cit., s. 128.

111 AIPN, 001708/4047, G. Banaszewski, Działalność młodzieżowych..., s. 37-41, 59.
} 
Jak słusznie zauważyła Anna Mikołejko, satanizm młodzieżowy lat osiemdziesiątych wpisywał się w obszar kontrkultury i mimo społecznej percepcji i twierdzeń samych satanistów, którzy próbowali mu nadać znacznie ruchu religijnego, poza tym obszarem nie występował, lokując się przede wszystkim na obrzeżach subkultury metalowej ${ }^{112}$. Sataniści czerpali przede wszystkim z mitu satanistycznego, który eksplorowali i wykorzystywali w swojej twórczości wykonawcy różnych odmian heavy metalu i to właśnie muzyka, a dokładnie cała towarzysząca jej otoczka (teksty utworów, okładki płyt, wywiady z muzykami, publikacje $\mathrm{w}$ fanzinach) była tym elementem, który wskazywali jako konstytuujący ich ogląd świata, poglądy i system wartości. Resztę uzupełniały informacje czerpane z mediów, rozmów z rówieśnikami, znajomymi, rzadko będące efektem lektur książek czy opracowań, nie wspominając już o pogłębionych kwerendach bibliotecznych czy prasowych. Satanizm był bez wątpienia formą młodzieżowego buntu przeciwko tradycyjnym strukturom rodzinnym i wyznaniowym, przede wszystkim Kościołowi katolickiemu. W odróżnieniu od innych subkultur, np. punka, nie był zjawiskiem ukierunkowanym na walkę z instytucjami politycznymi. Przejawiał się przede wszystkim w formach parareligijnych. Polscy sataniści do końca lat osiemdziesiątych XX w. nie wytworzyli żadnej spójnej doktryny. Nie powstał również żaden związek wyznaniowy, a wspólnoty satanistyczne miały pod względem organizacyjnym luźny i przypadkowy charakter ${ }^{113}$. W notatce sporządzonej w MSW w 1989 r. stwierdzono, iż grupy satanistyczne nie stanowiły poważnego zagrożenia dla bezpieczeństwa i porządku publicznego z uwagi na małą liczebność i brak struktur organizacyjnych, a „ruch satanistyczny nie jest i nie może być traktowany jako związek wyznaniowy”, a co najwyżej „jako niebezpieczny odprysk ogólnie rozchwianych postaw młodzieży przybierający formy wynaturzenia, a nawet dewiacji”114. Na zakończenie stwierdzono jednak, że satanizm jako negatywne społecznie zjawisko, kumulujące zarówno elementy subkultury młodzieżowej, jak i ideologii sprzecznej z wzorcami etycznymi akceptowanymi przez państwo i społeczeństwo, winien pozostawać w aktywnym zainteresowaniu SB MSW ${ }^{115}$.

Na przełomie lat osiemdziesiątych i dziewięćdziesiątych XX w. pojawiło się przekonanie, że satanizm przestał być atrakcyjną alternatywą dla kolejnego pokolenia młodzieży, a zainteresowanie nim zmalało na tyle, iż można mówić o jego zaniku $^{116}$. Jednak nie zniknął. Jak słusznie zauważył Piotr Szarszewski, „po prostu zakończył się pewien etap jego rozwoju - etap ostentacyjnego podkreślania przynależności do ruchu satanistycznego charakterystycznym ubiorem. Zniknięcie

112 A. Mikołejko, op. cit., s. 127-129.

113 Ibidem, s. 128-129.

114 AIPN, 0236/420, Informacja dot. grup o charakterze satanistycznym, [1989], k. 43-44.

115 Ibidem, k. 44.

116 A. Mikołejko, op. cit., s. 126. 
z ulicy osób noszących na szyi odwrócony krzyż czy pentagram doprowadziło do wyciągania pochopnych wniosków o końcu mody na satanizm"117. Otwarcie granic i integracja wolnej Polski z zachodnią Europą spowodowały swobodną wymianę idei. Pojawiły się nowe trendy i fascynacje. Satanizm znów stał się popularny wraz z pojawieniem się tzw. drugiej fali black metalu, w którym początkowo dominowały zespoły ze Skandynawii ${ }^{118}$. Towarzyszyły jej działania dalece wykraczające poza artystyczną ekspresję, jak podkreślanie konieczności walki $\mathrm{z}$ chrześcijaństwem i podpalenia kościołó $\mathrm{w}^{119}$. Black Metal znalazł w Polsce wielu fanów, a „powstała na satanistycznym i antychrześcijańskim fundamencie black metalu oraz wykazująca podobnie antyspołeczne tendencje, które często przekraczały granicę prawa, polska scena stanowiła odbicie norweskiej i szwedzkiej”'120. Media ponownie zaczęly informować o faktycznych i domniemanych zbrodniach, przestępstwach i wykroczeniach, których sprawcami były osoby uważające się za satanistów, a satanizm częściej niż wcześniej gościł na salach sądowych ${ }^{121}$. Jednak pomijając najgłośniejsze i jednocześnie najbardziej tragiczne przestępstwo, jakim była zbrodnia w Rudzie Śląskiej, gdzie w nocy z 2 na 3 marca 1999 r. w nieczynnym bunkrze dziewiętnastolatek i dwudziestojednolatek dokonali podwójnego zabójstwa, a ofiarami byli ich dziewiętnastoletnia koleżanka i siedemnastoletni kolega, w większości przypadków informacje o satanistach nie wywoływały już tak wielkich emocji jak w latach osiemdziesiątych.

\section{Fringes of the Subculture or a Religious Movement? Youth Satanism in Poland in the 1980s \\ (Summary)}

Youth Satanism appeared in Poland in the early 1980s, with the fashion for heavy metal music and the formation of a youth subculture gathered around this music and its subgenres. Youth Satanism formed and developed on the fringes of this subculture and never moved from the subculture phase to that of a religious movement. Contrary to a similar phenomenon present at the same time in Western (Atlantic) civilisation, in Poland, it had its specificities resulting from the fact that it developed in a non-democratic and at the same time largely traditional society, with the strong position of the Catholic Church, especially in the backcountry. In the country on the other side of the Iron Curtain, within the Soviet sphere of influence, the reception of trends and fashions coming from the USA and Western Europe was limited, difficult, and in many spheres forbidden institutionally. For these reasons, youth Satanism in Poland of the eighties was a specific phenomenon. On the one hand, it provoked the fascination of a small part of the youth; on the other hand, it caused concern of priests, educators, and the police, including the secret political police. These concerns were largely justified, given the crimes and offences committed by those claiming to be Satanists.

\footnotetext{
117 P. Szarszewski, op. cit., s. 43.

118 P. Czarnecki, op. cit., s. 6-7.

119 A. Sołtysiak, Współczesny satanizm..., s. 174-175; D. Patterson, op. cit., s. 159-170.

${ }^{120}$ D. Patterson, op. cit., s. 159-170.

121 P. Szarszewski, op. cit., s. 94-105.
} 
The author presents the cultural background to the emergence and development of modern Satanism in the USA and Western Europe, followed by its reception in Poland in the 1980s. He discusses the role of music and its performers, as well as the official media in the propagation of Satanism, and social reactions to its appearance, including the so-called Satanist hysteria and activities undertaken against Satanism and Satanists. He also reconstructs the map of youth Satanism and sketches its social portrait. Based on new, hitherto unused sources, the author verifies some of the claims formulated in the literature on the subject and poses further research questions.

\section{Bibliografia}

Bogaczyk F., Zetrzyj krew i graj dalej. Historia zespołu Turbo, Poznań 2019

Christiansen I., Satanizm w Europie - aktualny stan stosowanych działań profilaktycznych, w: Satanizm w Polsce i Europie. Stan obecny i profilaktyka, red. G. Fels, Ruda Śląska 2004, s. 39-74

Chwałczyk A., Kawaleria szatana, „Panorama Lubelska” 4 VII 1987

Czarnecki P., Koncepcja satanizmu $w$ drugiej fali Black Metalu, w: Kultura metalowa w przestrzeni rytualnej i medialnej, red. J. Kosek, Kraków 2019, s. 6-23

Di Nola A.M., Diabeł. O formach, historii i kolejach losu Szatana, a także o jego powszechnej a złowrogiej obecności wśród wszystkich ludów, od czasów starożytnych aż po teraźniejszość, Kraków 1997

Dyrendal A., Lewis J.R., Petersen J.A., The Invention of Satanism, Oxford 2016

Hoffmann B., Satanizm polski - mit czy rzeczywistość?, Warszawa 1991

Introvigne M., Satanism. A social history, Leiden-Boston 2016

Introvigne M., Satanizm. Historia, mity, Kraków 2014

Jędrzejewski M., Subkultury a przemoc w perspektywie psychoedukacji, socjalizacji i samorealizacji dzieci i młodzieży, Warszawa 2001

Kopiński M., Idea wolności w tekstach piosenek heavymetalowych lat 80. w twórczości TSA, Turbo i KAT, „Kwartalnik Młodych Muzykologów UJ” 2015, nr 4, s. 70-86

Kostrzewski R., Żyła M., Roman Kostrzewski. Głos z ciemności, Kraków 2016

La Vey A.S., Biblia szatana, Wrocław 1996

Lewis J.R., Satanism Today, Santa Barbara-Denver-Oxford 2001

Luijk van R., Children of Lucifer. The Origins of Modern Religious Satanism, New York 2016

Łagosz Z., Świerzowska A., Ciemniejsza strona ciemności - ścieżka lewej ręki w zachodniej tradycji ezoterycznej. Wybrane zagadnienia, „Zeszyty Naukowe Uniwersytetu Jagiellońskiego. Studia Religiologica" 2015, nr 1, s. 85-97

Mathews C., Modern Satanism, Anatomy of a Radical Subculture, Westport 2009

Matykowski R., Figisiak E., Społeczne i przestrzenne aspekty oddziaływania festiwalu muzyki rockowej w Jarocinie, w: Dźwięk w krajobrazie jako przedmiot badań interdyscyplinarnych, red. S. Bernat, Lublin 2008, s. 275-284

Mikołejko A., Polski satanizm młodzieżowy, „Przegląd Religioznawczy” 1992, nr 1, s. 117-129

Misiunia D., „Człowiek stwarza samego siebie”, czyli o okultystycznym projekcie antropologicznym, w: Ezoteryzm, okultyzm, satanizm w Polsce, red. Z. Pasek, Kraków 2005, s. 43-67

Nowak A.J. OFM, Satanizm, w: Satanizm, rock, narkomania, seks, red. A.J. Nowak OFM, Lublin 2001, s. $15-80$

Partridge C.H., Christianson E.S., The Lure of the Dark Side. Satan and Western Demonology in Popular Culture, New York 2014

Patterson D., Black Metal. Ewolucja kultu, Poznań 2016

Prinke R.T., Królestwo szatana, „Fakty” 1987, nr 27

Sieradzan J., W kręgu pojęć: ezoteryzm, okultyzm, satanizm, w: Ezoteryzm, okultyzm, satanizm w Polsce, red. Z. Pasek, Kraków 2005, s. 219-254 
Sołtysiak A., Satanizm tradycyjny, w: Religia. Encyklopedia PWN, t. 9, red. T. Gadacz, B. Milerski, Warszawa 2003, s. 43-44

Sołtysiak A., Satanizm wspótczesny, w: Religia. Encyklopedia PWN, t. 9, red. T. Gadacz, B. Milerski, Warszawa 2003, s. 44

Sołtysiak A., Satanizm współczesny, „Antropologia Religii” 5, 2013, s. 86-96

Sołtysiak A., Współczesny satanizm. Krótki przegląd głównych nurtów i ideologii, „Przegląd Religioznawczy" 2011, nr 2, s. 163-178

Stawiński P., Społeczny odbiór satanizmu. Źródła i dynamika przekonań na przykładzie Stanów Zjednoczonych lat 80., „Państwo i Społeczeństwo” 8, 2008, nr 1, s. 151-163

Stawiński P., Współczesny mit miejski. Uwagi na temat kształtowania się i społecznego funkcjonowania stereotypu satanisty, „Przegląd Religioznawczy” 1997, nr 4, s. 155-164

Szarszewski P., Satanizm w Polsce. Próba analizy zjawiska, Warszawa 2004

Szubrycht J., Histeria satanizmu, „Polityka” 2015, nr 44, s. 88-90

Tracz B., Ślaski blues czy ślaski metal?, „CzasyPismo” 2014, nr 1, s. 36-41

Wolański R., Leksykon polskiej muzyki rozrywkowej, t. 2-3, Warszawa 2003

Wójcik J.W., Od hipisów do satanistów, Kraków 1992

Zawadzki M., Komunikacja werbalna i niewerbalna subkultury satanistów i metalowców. Podobieństwa i różnice obu grup, w: Ezoteryzm, okultyzm, satanizm w Polsce, red. Z. Pasek, Kraków 2005, s. $181-195$

Zwoliński A., Satanizm, Radom 2007

Bogusław Tracz, historyk, doktor nauk humanistycznych, pracownik Oddziałowego Biura Badań Historycznych Instytutu Pamięci Narodowej w Katowicach. W swoich badaniach koncentruje się na historii społecznej ziem polskich w latach 1945-1989 ze szczególnym uwzględnieniem województwa śląskiego/katowickiego, dziejach nieformalnych grup młodzieżowych, przemianach kultury i obyczajów w czasach PRL oraz Polskiej Zjednoczonej Partii Robotniczej w lokalnym systemie władzy.

Kontakt: boguslaw.tracz@ipn.gov.pl 